\title{
Det nordslesvigske valutaspørgsmål 1918-1920 og kronemøntens indførelse
}

\author{
af MORTEN ANDERSEN
}

Den 15. juni 1920 blev Nordslesvig genforenet med kongeriget Danmark efter at have været under tysk herredømme siden krigen i 1864 . Genforeningen med Danmark betød, at den danske kronemønt skulle indføres i Nordslesvig. Et valutaspørgsmål af den art giver ofte anledning til politiske divergenser. Spørgsmålet om omvekslingen af nordslesvigernes tyske Reichsmark til danske kroner var heller ikke uden problemer. Artiklen her er en forkortet udgave af forfatterens historiespeciale ved Syddansk Universitet, Odense 2001.

\section{Introduktion}

Det nordslesvigske valutaspørgsmål 1918-20 var vanskeligt at få løst af flere årsager. For det første fordi mange forskellige interesser var på spil i dette spørgsmål. Valutaspørgsmålet havde betydning for hver enkelt nordslesvigers privatøkonomi og for det nordslesvigske erhvervslivs overgang til det danske marked. Men valutaspørgsmålet drejede sig også om, hvad den danske statskasse kunne yde af økonomisk støtte til Nordslesvig i forbindelse med genforeningen. Den tyske krigsøkonomi havde tæret hårdt på Nordslesvig siden august 1914. Ernæringsforholdene var blevet stadig dårligere, efterhånden som krigen trak ud, og Nordslesvig manglede de mest basale ressourcer, for at landbruget igen kunne brødføde befolkningen. Nordslesvigerne forventede ikke kun en forbedring af deres nationalpolitiske forhold, men også en forbedring af deres økonomiske forhold ved genforeningen. I den forbindelse var valutaspørgsmålet helt centralt.

Mest af alt blev valutaspørgsmålet vanskeliggjort af den tyske Reichsmarks dramatiske kursfald. Bag markkursens fald lå flere forskellige faktorer, især den tyske krigsfinansiering og krigsøkonomi. Markkursens fald havde nær sammenhæng med den tyske inflation, der varede 9 år fra efteråret 1914 til efteråret 1923, hvor hyperinfla- 
tionen blev bremset med en fuldstændig møntreform. Markkursens udvikling overfor kronen i perioden 1914 til 1920 ses i tabellen nedenunder.

Tabel 1.

\begin{tabular}{|c|c|c|c|c|c|c|c|}
\hline & \multicolumn{7}{|c|}{$\begin{array}{l}\text { Markkursen noteret på Hamborg børs 1914-1920 } \\
\text { Kr. pr. } 100 \text { mk. Månedlig gennemsnit }\end{array}$} \\
\hline & 1914 & 1915 & 1916 & 1917 & 1918 & 1919 & 1920 \\
\hline Januar & 88,90 & 87,15 & 67,79 & 61,23 & 62,90 & 46,28 & 9,52 \\
\hline Februar & 88,95 & 85,95 & 65,82 & 60,65 & 62,13 & 42,51 & 7,11 \\
\hline Marts & 89,00 & 83,50 & 62,43 & 56,39 & 63,59 & 38,29 & 7,77 \\
\hline April & 89,00 & 80,40 & 61,63 & 54,40 & 63,18 & 32,77 & 9,94 \\
\hline Maj & 89,00 & 78,96 & 61,38 & 53,54 & 62,88 & 33,24 & 14,02 \\
\hline Juni & 89,10 & 77,71 & 62,60 & 49,00 & 60,38 & 30,85 & 15,55 \\
\hline Juli & 89,05 & 78,65 & 63,65 & 48,48 & 55,24 & 29,09 & 15,64 \\
\hline August & 89,20 & 78,55 & 63,76 & 46,62 & 52,67 & 23,74 & 14,30 \\
\hline September & 89,15 & 79,51 & 63,99 & 45,48 & 50,89 & 19,09 & 12,69 \\
\hline Oktober & 87,00 & 78,62 & 64,08 & 43,42 & 55,69 & 17,26 & 10,85 \\
\hline November & 85,00 & 74,91 & 63,26 & 43,87 & 51,17 & 12,47 & 10,12 \\
\hline December & 87,20 & 70,64 & 60,24 & 57,63 & 45,19 & 11,38 & 9,57 \\
\hline Gennemsnit & 88,38 & 79,55 & 63,39 & 51,73 & 57,16 & 28,08 & 11,42 \\
\hline
\end{tabular}

Kilde: Statistisk Aarbog 1914-23. Tabeller for vekselkursen noteret på Hamborg.

En omveksling af tyske Reichsmark til danske kroner efter den officielle avista- eller dagskurs i overgangstiden 1918 til 1920 ville koste nordslesvigerne dyrt, da markformuer opstået før 1914 ville reduceres kraftigt dermed. Af den årsag blev en omveksling til fredskurs, den kurs, marken havde før krigsudbruddet i august 1914, et mål, der blev arbejdet for i vide nordslesvigske kredse. Denne kurs blev også benævnt parikurs og lå på omtrent 89 kroner for 100 mark. En omveksling til fredskurs fandt imidlertid ikke megen velvilje i de danske kredse, der skulle gennemføre valutaordningen. Her vejede hensynet til den danske statskasses finanser og ydeevne tungt. Og jo mere markkursen faldt, jo dyrere ville en omveksling af nordslesvigernes Reichsmark til fredskurs blive for den danske stat.

En politisk forhandlings- og beslutningsproces omkring det nordslesvigske valutaspørgsmål blev indledt i foråret 1919. Processen blev afsluttet den 20. maj 1920 med kronemøntens indførelse i Nordslesvig, omtrent en måned før den officielle genforening. Valutaspørgsmålets ordning fik et noget andet udseende, end de fleste nordslesvigere havde forventet og blev senere udsat for megen kritik. Den 
Oluf Bech, direktor for Nationalbankens filial $i$ Kolding 19011923, og borgmester $i$ Kolding 1916-1923. Det var Oluf Bech, der fik ansvaret for kronemontens indførelse $i$ Nordslesvig den 20. maj 1920. Oluf Bech var også medlem af Sonderjysk kroneudvalg. Portrætfoto $1920 \mathrm{i}$ Kolding Stadsarkiv.

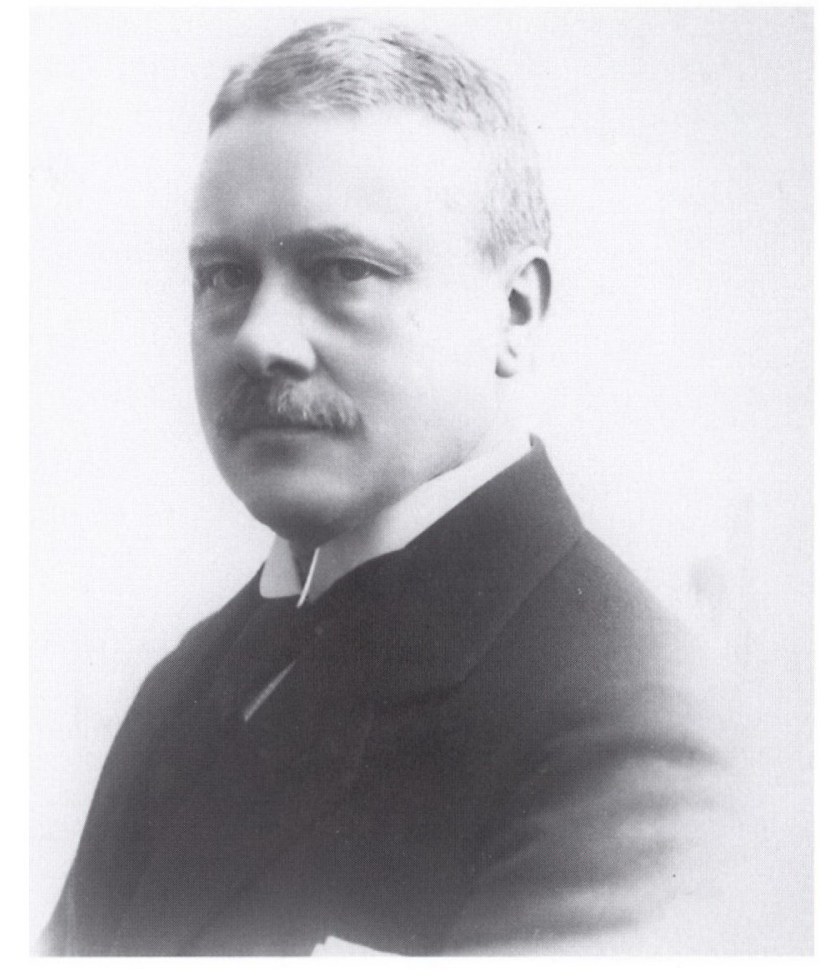

økonomiske støtte fra Danmark svarede med andre ord ikke til nordslesvigernes forventninger. Denne artikel vil omhandle den politiske beslutningsproces og de økonomiske og politiske overvejelser bag den nordslesvigske valutaordning, som den så ud med lovene omkring kronemøntens indførelse i Nordslesvig den 20. maj 1920. Først vil der blive redegjort for ordningen, som den blev fastlagt i 1920 og derefter for de mange forhandlinger, som gik forud.

Lovene om Kronemøntens indførelse, Udligningskassen og Lånekassen

Den 14. maj 1920 udstedte den internationale kommission for Slesvig, C.I.S, en anordning om kronemøntens indførelse i 1. zone. C.I.S var nedsat af ententemagterne på fredskonferencen i Paris i foråret 1919 og administrerede de to afstemningszoner i Slesvig i perioden 10. januar til 16. juni 1920. Anordningen om kronemøntens indførelse gjor- 
de dansk møntlovgivning gældende fra og med den 20. maj 1920, hvormed dansk mønt var lovligt betalingsmiddel mand og mand imellem og ved offentlige kasser. Omregningskursen ved betaling til de offentlige kasser fastsattes efter den på Københavns børs officielt noterede dagskurs for Reichsmark og kunne kun ændres ved bestemmelse fra kommissionen og administratoren for de sønderjydske landsdele i Aabenraa. Betalinger mand og mand imellem skulle foregå til dagskurs, og tysk mønt kunne anvendes lovligt indtil videre. Desuden blev der udstedt en anordning om valg af medlemmer til et valutaråd i 1. zone, en anordning om oprettelsen af en lånekasse for de sønderjydske landsdele, samt en anordning om totalforbud mod ind- og udførsel af varer til og fra afstemningsområdet og mellem 1.- og 2. zone, med undtagelse af indførsel af forsyninger til 1. zone fra Danmark. ${ }^{1}$

Bag kommissionens anordninger om kronemøntens indførelse lå tre love udarbejdet af den danske centraladministration. Det drejede sig om loven om kronemøntens indførelse, loven om en udligningskasse, og loven om en lånekasse. Loven om kronemøntens indførelse gjorde dansk møntlovgivning gældende og dansk mønt lovligt betalingsmiddel ved offentlige kasser og mand og mand i mellem. ${ }^{2}$ Udligningskassen var ment som en kasse, der skulle udligne de indtægts- og formuetab, som krigen og inflationen havde påført de nordslesvigske borgere. Kassen stillede 350 kroner til rådighed per indbygger i Nordslesvig. Indbyggertallet fastsattes efter folketællingen fra 1910, hvor tallet havde været 167.603 indbyggere. Det gav udligningskassen et samlet beløb på 58,66 millioner kroner at arbejde med. Erstatninger kunne kun ydes til indbyggere, der havde boet i Nordslesvig siden 1 . januar 1914, og de enkelte borgere skulle kunne påvise et tab ved sammenligning af deres formuer den 1. januar 1914 og den 1. januar 1920 for at kunne komme $i$ betragtning. Erstatningen for formuetab blev givet efter en glidende skala, således at mindre formuer fik en højere dækning end større formuer. Personer med formuer, der den 1. januar 1914 udgjorde indtil 5.000 mark, skulle have deres tab erstattet til parikurs, 8 kroner for 9 mark. Personer med formuer fra 5.000 mark indtil 15.000 mark skulle have de første 5.000 tabte mark erstattet til pari, de næste 5.000 til kurs 45 og resten til en af forvaltningsrådet fastsat kurs, dog ikke over kurs 45, for så vidt udligningskassens rådighedsbeløb rakte. For hver følgende 10.000 mark over de 15.000 kunne erstatninger gives til en kurs faldende med 5 fra de 45 . Familieforsør- 


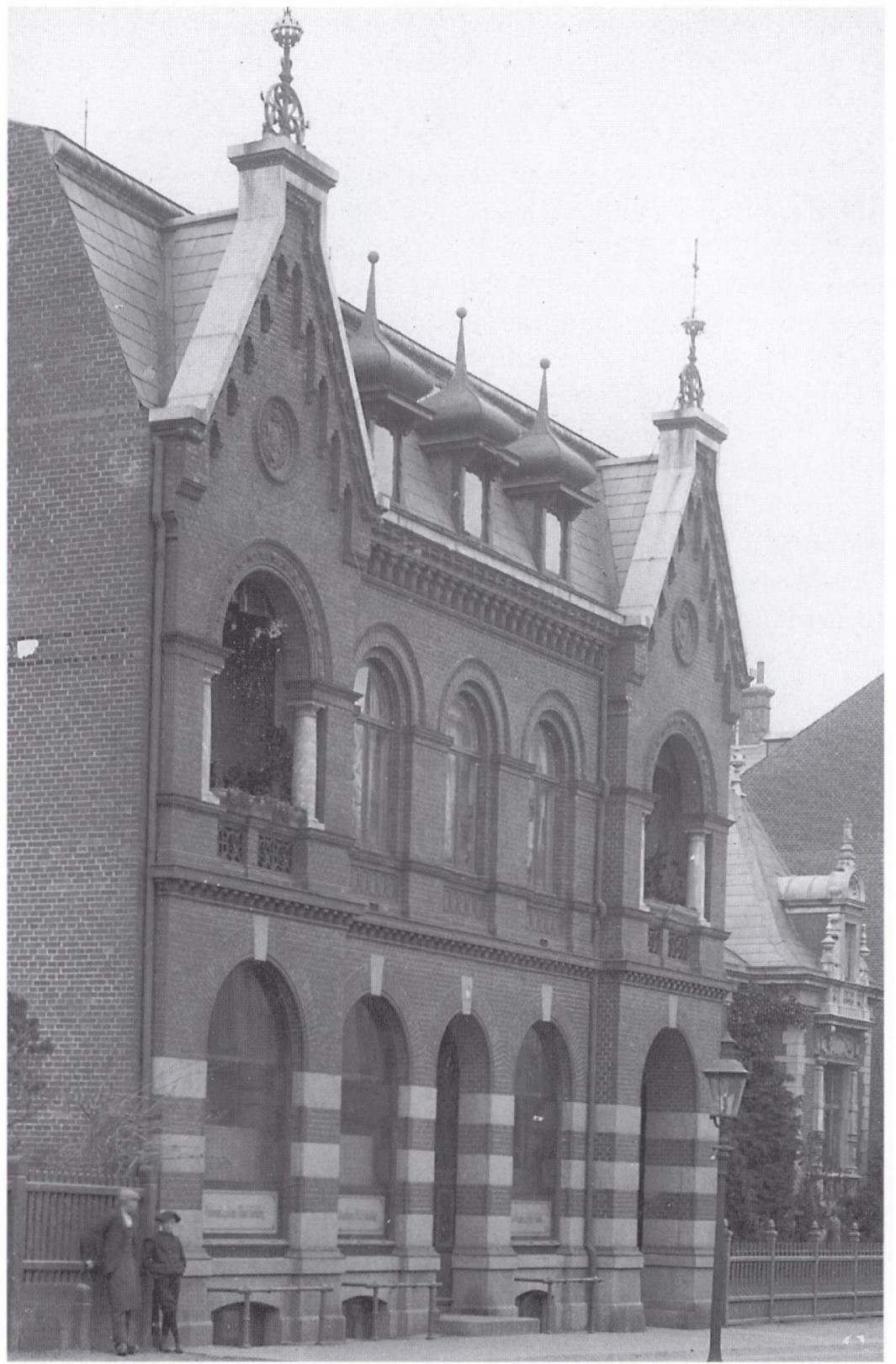

Nationalbankens filial $i$ Kolding. Her samlede Nationalbanken samtlige monter og sedler til indforelse $i$ Nordslesvig $i$ dagene for den 20. maj 1920. Bygningen er $i$ dag nyrenoveret og huser blandt andet det svenske konsulat. Foto $1920 \mathrm{i}$ Kolding Stadsarkiv. 
gere fik fuld erstatning, mens ikke-familieforsørgere måtte nøjes med $2 / 3$ af de efter reglerne fastsatte erstatningssummer. Formuer måtte ikke bringes over 25.000 kroner per individ ved erstatningen. Dertil kom årlige indtægtstilskud til personer, der levede af renter og pension, der ikke blev overtaget af den danske stat. Også her blev en glidende skala anvendt, således at mindre pensioner fik en relativ højere dækning end større pensioner. Under særlige omstændigheder kunne reglerne anvendes på danske statsborgere, der stammede fra Nordslesvig, og som var flyttet til Nordslesvig fra Tyskland efter 1914, og personer der havde været bosat i Nordslesvig, men som var flyttet til Danmark og var henvist til at leve af renter eller pension i tyske mark. Personer med formuer, der var opstået ved arv eller formuer, der var opstået i tidsrummet 1. januar 1914 til 1. januar 1919, og siden tabt, kunne under særlige omstændigheder komme i betragtning til erstatning. ${ }^{3}$

Erstatningerne skulle administreres af et valutaråd, hvis medlemmer skulle vælges efter de regler, der var opstillet i den internationale kommissions anordning fra den 14. maj 1920. De fire nordslesvigske kredse blev bedt om hver at udnævne to repræsentanter, mens erhvervsorganisationerne for landbrug, håndværkere og industri, handlende, arbejdere, fiskere og privatfunktionærer blev bedt om hver at udnævne én repræsentant. Sammen med rådets formand, generaldirektør for skattevæsenet Michael Kofoed, skulle disse 14 nordslesvigske mænd gennemføre udligningskassens erstatninger. Sønderjysk Valutaråd, som rådet blev kaldt, fik en relativ høj grad af autonomi i fastlæggelsen af de mere konkrete principper for tildeling af erstatninger. Rådet delte erstatningerne op i to grupper. De såkaldte pligtmæssige erstatninger, som hovedsagelig gjaldt personer med 1914formuer på indtil 10.000 mark og renteindtægter indtil 2.000 mark, og ikke-pligtmæssige erstatninger, som var til personer med formuer eller renteindtægter derover. Valutarådet havde i november 1920 så meget overblik over de pligtmæssige erstatninger, at de kunne fastsætte præcise omregningskurser for formuer over 10.000 mark inden for lovens rammer. Valutarådets omregningskurser ses i tabel 2 nedenunder. 
Tabel 2.

\begin{tabular}{|c|c|}
\hline \multicolumn{2}{|c|}{ Udligningskassens erstatningsskala for formuetab } \\
\hline $\begin{array}{l}\text { Formue 1. Jan. } 1914 \\
\text { i Rigsmark }\end{array}$ & $\begin{array}{l}\text { Erstatningskurs for tab under } \\
\text { krig og inflation }\end{array}$ \\
\hline-5.000 & 89 (Pari) \\
\hline $5.000-25.000$ & 45 \\
\hline $25.000-35.000$ & 40 \\
\hline $35.000-45.000$ & 35 \\
\hline $45.000-55.000$ & 30 \\
\hline $55.000-65.000$ & 25 \\
\hline
\end{tabular}

Kilde: Beretning om Virksomheden i Udligningskassen (1922).

Som sagt var formuen i 1914 udgangspunkt, men det var det tabte beløb, der erstattedes. Havde formuen i 1914 været på indtil 5.000 mark, erstattedes tabet til parikurs. Havde formuen været over 5.000 mark indtil 25.000 mark, erstattedes de første 5.000 tabte mark til pari, de næste til kurs 45 . Havde formuen i 1914 været over 25.000 indtil 35.000 mark erstattedes de første 25.000 tabte mark som ovenfor, resten til kurs 40 og så fremdeles. Rente- og pensionstilskudsskalaen ses i tabel 3 nedenunder.

Tabel 3.

\begin{tabular}{|c|c|}
\hline \multicolumn{2}{|c|}{$\begin{array}{l}\text { Udligningskassens erstatningskala } \\
\text { for rente og pensionstilskud }\end{array}$} \\
\hline $\begin{array}{l}\text { Renter og pension } \\
\text { (Indtægt i mark 1920) }\end{array}$ & $\begin{array}{l}\text { Erstatningskurs for } \\
\text { indtægtstilskud }\end{array}$ \\
\hline-2.000 & 89 (Pari) \\
\hline $2.000-4.000$ & 45 \\
\hline $4.000-6.000$ & 40 \\
\hline $6.000-8.000$ & 35 \\
\hline $8.000-10.000$ & 30 \\
\hline $10.000-12.000$ & 25 \\
\hline
\end{tabular}

Kilde: Beretning om Virksomheden i Udligningskassen (1922).

Havde man en rente- eller pensionsindtægt på indtil 2.000 mark om året i 1920, fik man et tilskud, således at den samlede indtægt svarede til en omveksling af $\mathbf{2 . 0 0 0}$ mark til parikurs. Rente- eller pensionsindtægter mellem 2.000 og 4.000 mark fik de første 2.000 omsat til parikurs og resten til kurs 45 og så fremdeles. Den samlede årsindtægt måtte ikke forøges til mere end 4.000 kroner.

Lånekassen fik et beløb på 10 millioner kroner stillet til rådighed, med hvilke kassen kunne yde driftslån til håndværkere, handlende 


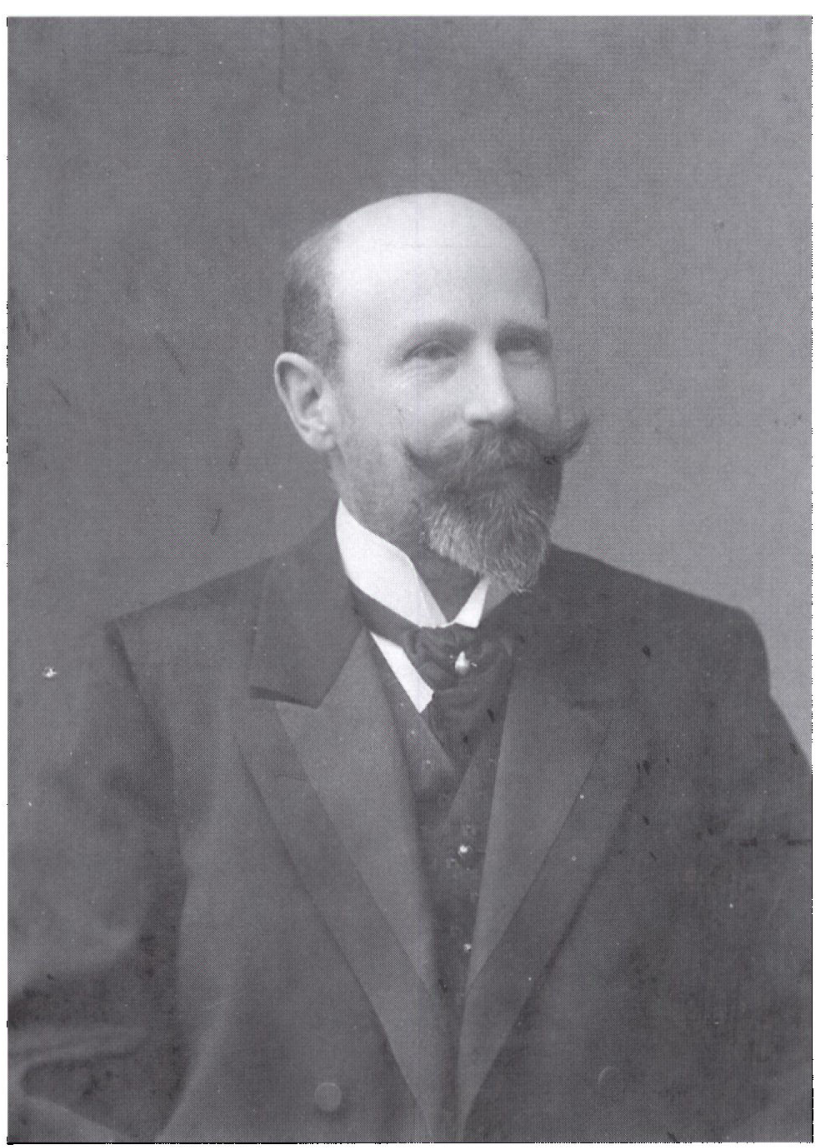

Christian Hübbe (1868-1945). Direktør for Haderslev Bank 1901-39. Christian Hübbe var talsmand for den store gruppe af nordslesvigere, der onskede en omveksling af hele markbestanden til fredskurs ved kronemontens indforelse i Nordslesvig. Portrætfoto $1907 i$ Haderslev Byhistoriske Arkiv.

og landbrugere, der som følge af krigen og inflationen ikke kunne skaffe sig den fornødne driftskapital til opretholdelse af en virksomhed. Lånene kunne ikke overstige 10.000 kroner og forrentedes med $4 \%$ årligt. I særlige tilfælde kunne rente- og afdragsfrie lån ydes i op til tre år. Kassen skulle administreres af det kroneudvalg, som på foranledning af det midlertidige ministerium for sønderjyske anliggender var blevet nedsat den 18. december 1919 for at afhjælpe problemerne omkring kronemøntens indførelse i Nordslesvig. ${ }^{4}$

Udover midlerne til udlignings- og lånekassen måtte den danske stat rejse midler til følgende ordninger. De fire store banker i Nordslesvig, Haderslev Bank, Nordslesvigsk Folkebank i Aabenraa, Banken for Als og Sundeved i Sønderborg og Tønder Landmandsbank 
tildeltes hver et lån på 3 millioner kroner til en rente på 5\%. 2,35 millioner kroner $i$ alt måtte desuden stilles til rådighed for fem andre banker. 72 nordslesvigske sparekasser skulle hver modtage lån på gennemsnitlig 20.000 kroner. 10 millioner kroner blev stillet til rådighed til opkøb af obligationer fra den nyoprettede Sønderjyllands Kreditforening, for at støtte kursen på foreningens første obligationsrække. Sønderjyske arbejdere fik et løntillæg i ugen før kronemøntens indførelse på samlet 2 millioner kroner. I alt drejede disse ordninger vedrørende kronemøntens indførelse i Nordslesvig sig om, at den danske stat stillede omtrent 97 millioner kroner til rådighed. ${ }^{5}$ Fordelingen af de 97 millioner kroner ses i tabel 4 nedenfor.

Tabel 4.

\begin{tabular}{lc}
\hline \multicolumn{1}{c}{$\begin{array}{c}\text { Rådighedsbeløb rejst af den danske stat ved } \\
\text { kronemøntens indførelse den 20. maj 1920 }\end{array}$} \\
\hline Beløb i mill. kr. \\
\hline Formål & 59 \\
Udligningskassen & 10 \\
Lånekassen & 10 \\
Støtteopkøb af Kreditforeningsobligationer & 2 \\
Løntillæg til arbejdere & \\
Lån til banker og sparekasser & 3 \\
Haderslev Bank & 3 \\
Nordslesvigsk Folkebank & 3 \\
Banken for Als og Sundeved & 3 \\
Tønder Landmandsbank & 1 \\
Sønderborg Bank & 1 \\
Nordslesvigsk Bank & 0,2 \\
Løgumkloster Bank & 0,1 \\
Haderslebener Kreditbank & 0,05 \\
Haderslev Amts Folkebank & 1,44 \\
72 sparekasser (20.000 kr.72) & 96,79 \\
\hline I alt &
\end{tabular}

Kilde: Rigsdagspartiernes sønderjydske Udvalg. Forhandlingsprotokol (s. 977-982).

\section{Nordslesvig under krig og inflation}

Før vi begiver os ind i beslutningsprocessen bag kronemøntens indførelse, skal vi se på de økonomiske forhold i Nordslesvig under og efter 1. verdenskrig, der fik stor betydning for valutaspørgsmålet. Hvorvidt det nordslesvigske landbrug, der var egnens hovederhverv i 1918, kom godt eller skidt i gennem 1. verdenskrig, er svært at afgø- 
re entydigt. P.A. Callø, direktør for Sønderjyllands Kreditforening 1920-60, giver i sin beretning om de okonomiske forhold i Sønderjylland i overgangstiden følgende vurdering: Sønderjylland er jo et Bondeland med faa og smaa Kobstæder. Landbruget er det bærende Erhverv, og dette har været et Held for Landsdelen, eftersom Landbruget et det Erhverv, der har lidt mindst under Krigen og dens Følger. ${ }^{6}$ P. A. Callø henviser til, at store investeringer fra tiden før 1914 betød, at landbruget stod godt rustet før krigen. Han nævner også landbokvindernes evne til at overtage driften på gården, tilstedeværelsen af russiske krigsfanger som arbejdskraft, og de relativt gode muligheder for krigsorlov, som landmændene havde under krigen. Ved krigens slutning stod mange landmænd desuden med store pengemidler. For det første fordi manglen på kunstgødning, kraftfoder og arbejdskraft under krigen havde forringet produktiviteten og gjort det attraktivt at omsætte driftsmidlerne, som jord, dyr og maskiner, i kontanter. For det andet fordi tvangsafleveringer og restriktionspolitikken indebar realisering af driftsmidlerne i sig selv, og for det tredje fordi nogle landmænd tjente godt på smughandel uden om restriktionerne. Det var især den forøgede likviditet Callø henviste til, da han vurderede landbrugets stilling efter krigen som relativ god. Men spørgsmålet er, hvad kapitalen var værd, når inflationen tages med i betragtning?

Det nordslesvigske landbrug oplevede et stærkt fald i produktiviteten under 1. verdenskrig. Krigsøkonomien og restriktionerne spillede her en stor rolle. Kornhandelens monopolisering i 1915 og oprettelsen af lokale Reichsgetreidestellen i alle kredse, hvorved kontrollen af landbruget øgedes mærkbart, var upopulære foranstaltninger, der trak produktiviteten ned. Tvangsafleveringerne var ikke mindre upopulære. Hestebestanden var allerede i 1914 faldet med 20\%, og svinebestanden i 1915 reduceret med 60\%.7 De af den tyske stat fastsatte maksimalpriser blev hurtigt til et stort problem. Maksimalpriserne tog ikke del i de generelle prisstigninger, og det betød at landmændenes indtjening ikke svarede til udgifterne. For landmændene blev det sorte marked mere og mere attraktivt, som krigen gik. Her var indtjeningen væsentlig bedre end på det legale marked. Det kom blandt andet til udtryk ved en stor nedgang i mejeriernes mælkemængde i løbet af krigen. ${ }^{8}$ Der er ingen tvivl om, at landbruget havde en fordel $i$ at have adgang til fødevarer til egen ernæring, men også som salgsvarer. På trods af restriktionerne havde man noget at handle med, og de lokale myndigheder berettes da også i mange tilfælde at have væ- 


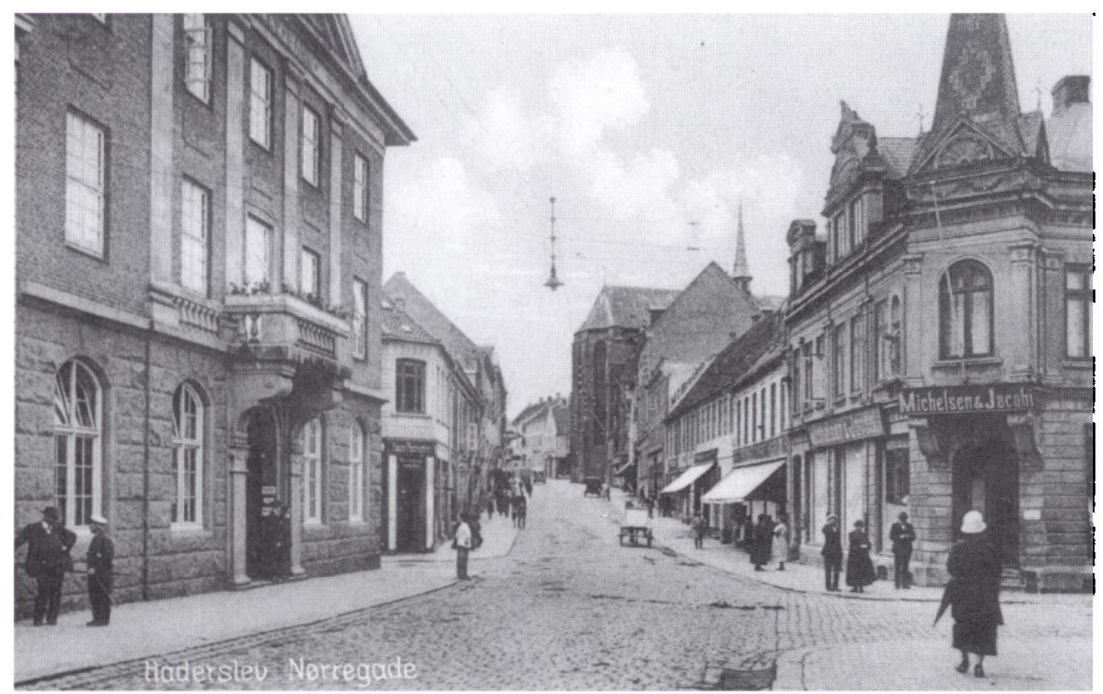

Haderslev Bank og Norregade $i$ Haderslev omkring 1920-25. På venstre side ses Haderslev Banks bygning Nørregade 30 indviet $i$ 1916. Haderslev Bank, en af de fire store nordslesvigske banker $i 1920$, blev grundlagt $i 1875$. I 1969 fusionerede Haderslev Bank med Privatbanken, $i$ dag Nordeabank. Postkort 1920-25 i Haderslev Byhistoriske Arkiv.

ret bestikkelige. Personlige forbindelser var afgørende. Der har derfor været store individuelle forskelle på, hvorledes landbruget kom igennem krigen fra brug til brug. ${ }^{9}$

Ifølge P. A. Callø var de hårdest ramte i Nordslesvig håndværkerne. Deres materialer blev enten beslaglagt eller var utilgængelige under krigen. Desuden kunne ingen erstatte håndværkeren, når denne var i krig, som tilfældet var med landmændene. Industrien i Nordslesvig, der hovedsagelig bestod af teglværkerne ved Egernsund, havde allerede inden krigen haft vanskeligheder ved at klare den centraltyske konkurrence, og krigen gav ikke de store ændringer her. ${ }^{10}$

Krigsøkonomien mærkedes også i de nordslesvigske købstæder. Den 1. oktober 1914 fastsatte magistraten i Haderslev maksimalpriser på kartofler, 16. februar 1915 på brød og fra 1. marts 1915 indførtes brødrationering. En levnedsmiddelkommission blev nedsat, og byen opkøbte fødevarer for at kunne oprette et permanent udsalg af varer som ris, gryn, lammekød, klipfisk, røget skinke, flæsk og grøntsagskonserves til byens befolkning. De nordslesvigske købstæder nød dog i modsætning til de tyske industribyer godt af nærheden til landdi- 
strikterne. Fælleslandboforeningen for Nordslesvig leverede således gratis mælk og grøntsager til de større byers bespisningssteder for fattige. I november 1915 opfordrede Fælleslandboforeningen landmændene til at udvise solidaritet med de fattige ved at danne velfærdskomiteer i sogne og landsbyer. ${ }^{11}$

Som tiden gik, blev det imidlertid sværere at skaffe fødevarerne, og i 1917 blev mangelsituationen alvorlig. Alle fødevarer var afleveringspligtige og fordeltes centralt. Nordslesvig kom til at lide under hensynet til de store tyske industribyer, som fik størstedelen af de $i$ Nordslesvig producerede fødevarer. Det sorte markeds opblomstring havde også en del af skylden for fødevaremangelen. Dertil kom, at fødevarepriserne steg mærkbart. Krav om tilsvarende lønstigninger fulgte naturligvis efter. I labet af 1916 var lønniveauet i Haderslev steget til $25-30 \%$ over førkrigsniveau. Ved årsskiftet 1918-19 var lønningerne helt oppe på 100-150\% over førkrigsniveau. Men prisniveauet var steget $300-400 \%$ over førkrigsniveau, så lønstigningerne rakte ikke langt. ${ }^{12}$

\section{Genforeningshåb og nødstilstand}

I sommeren og efteråret 1918 blev det klart, at Tyskland før eller siden ville lide nederlag i krigen. Dermed opstod også spørgsmålet om Nordslesvigs fremtidige tilhørsforhold. Genforeningshistorien tog sin begyndelse. Den 23. oktober 1918 stillede H.P. Hanssen i den tyske rigsdag krav om en løsning af det nordslesvigske spørgsmål med selvbestemmelsesretten som grundlag. Den 16. og 17. november 1918 holdt Nordslesvigsk Vælgerforening, der var de dansksindede nordslesvigeres politiske organisation, tilsynsrådsmøde på "Folkehjem « i Aabenraa og tog stilling til en kommende folkeafstemning. I december 1918 blev det slesvigske spørgsmål rejst officielt over for de allieredes regeringer, og så ventede forhandlinger ved fredskonferencen $i$ Paris i foråret 1919.

Genforeningstankerne blev i mellemtiden forstyrret af den tyske revolution, der brød ud i Kiel den 3. november og udmundede i dannelsen af Weimarrepublikken den 9. november 1918. Der blev dannet soldater-, arbejder- og bonderåd, således også i Nordslesvig. For nordslesvigerne, særligt i landbefolkningen, handlede oprettelsen mere om at overtage myndigheden fra de tyske kommuneforstandere end om at gennemføre en revolution. Revolutionsbevægelsen var $\mathrm{i}$ 


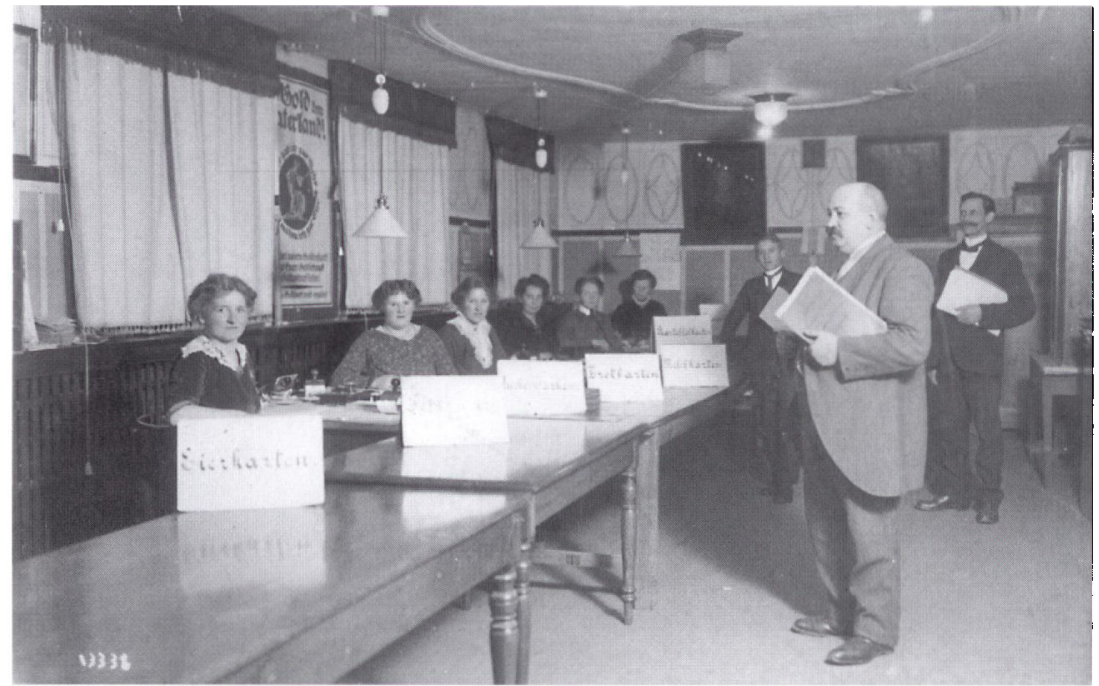

Rationeringskortudlevering på Haderslev Rådhus omkring 1917. Rationeringskortene var en folge af vareknapheden under 1. verdenskrig. Lxg mærke til plakaten i midten, "Gold dem Vaterland", en opfordring til borgerne om at indlevere guld til rigsbanken. Den tyske rigsbank lod seddelpressen rulle under krigen. Seddeludstedelsen blev finansieret ved krigslånsobligationer og borgernes indlevering af guld-og sølvmonter. Den politik var en af hovedårsagerne til at inflationen lob ud af kontrol. Foto: Haderslev Byhistoriske Arkiv.

det hele taget uden den store politiske betydning i Nordslesvig, hvor det først og fremmest var grænsespørgsmålet, der optog sindene. Soldater- og arbejderrådenes arbejde lå i demobiliseringen og fødevareforsyningen lokalt. En række kontrolopgaver havde rådene også, blandt andet kontrol af at den nyindførte otte-timers arbejdsdag blev overholdt og af den almindelige administration. ${ }^{13}$

Forsyningssituationen var dog alvorlig nok. Den 30. november 1918 blev Haderslevs varebeholding opgjort til 15 sække boghvedegryn, et parti nudler, 7200 pund kunsthonning og en mængde hvidkål. Til en befolkning på cirka 14.000 var dette meget beskedent. ${ }^{14} \mathrm{I}$ Flensborg Avis kunne man den 12. februar $1919 \mathrm{i}$ en artikel med titlen "Et mørkt Billede af vor Hjemstavn“ læse følgende om situationen: Leonedsmiddelsporgsmålet er ogsaa stadig blevet vanskeligere, trods det at Sonderjylland er et agerdyrkende og kvægavlende land. Ved de evige Restriktioner svinder kreaturtallet ind, $i$ Haderslev Amt er det gaaet ned med halvdelen, $i$ de andre Amter er forholdet noget lignende. Kunstgødning er ikke til at skaffe, Kraftfoder findes ikke, Høet er knapt og Roerne bruges til Men- 
neskeføde. I Fjor var der mange Mennesker, som i flere Maaneder levede af Roer og Roeafkog. Landbruget er nu naaet til den yderste Grænse af, hvad det kan yde. Mælkeleveringen til Mejerierne er dalet til et minimum. Mælken og Smorret bliver gjort endnu knappere ved at der sendes Mælk til Hamborg eller Torringsanstalter. Der uddeles Sødmælk til Børn under 6 Aar, ellers kun efter Lxgeattest til syge, til frugtsommelige og diegivende Kvinder.

Bag artiklen står læge Hans Lausten-Thomsen fra Skærbæk. Selvom Flensborg Avis havde politiske interesser i at fremstille situationen under det tyske styre så dårlig som muligt, er der ikke tvivl om, at ernæringssituationen i hele Tyskland var alvorlig. Reguleringsøkonomien var ikke hørt op med revolutionen. Maksimalpriser og tvangsafleveringer betød, at smughandelen tog til. Da en folkeafstemning om Nordslesvigs nationale tilhørsforhold sandsynligvis ville komme, og Nordslesvig derved ville blive dansk, bekymrede de tyske myndigheder sig ikke synderligt om forsyningen dertil. Kultilførslen sydfra blev med tiden et stort problem i Nordslesvig. Samtidig opkøbte den tyske regering stadig varer i Nordslesvig og sendte dem sydpå, hvilket forværrede situationen. Prisstigningerne fortsatte desuden med uformindsket styrke efter våbenstilstanden.

\section{Nødpenge}

Nødstilstanden eksisterede også inden for pengeverdenen. Den tyske rigsbanks jagt på guld- og sølvmønter betød, at der allerede inden krigen opstod mangel på almindelig skillemønt i hele Tyskland, og nødpenge blev fra 1913 et almindeligt fænomen. De enkelte kommuner kunne lovligt udstede nødpengesedler fra 1917. Der skulle være dækning i kommunekassen for de udstedte nødsedler, men det krav blev sjældent overholdt. Her ligger der også en medvirkende årsag til inflationen. Kommunerne fandt snart ud af, at sedlerne kunne være en god forretning, særligt da sedlerne blev samleobjekter. Nødpengesedlerne var udtryk for et tilgodehavende hos den pågældende kommune, men hvis de aldrig indløstes var pengene tjent, og ellers gjorde inflationen fortjenesten god.

I Slesvig-Holsten og Hamborg udkom i alt 342, i Nordslesvig 100 forskellige slags nødpengesedler, hvilket er $25 \%$ af alle tyske nødpenge. De nordslesvigske nødpenge blev i tiden op mod afstemningerne mere og mere kunstfærdigt udformet og indgik i den nationale propa- 


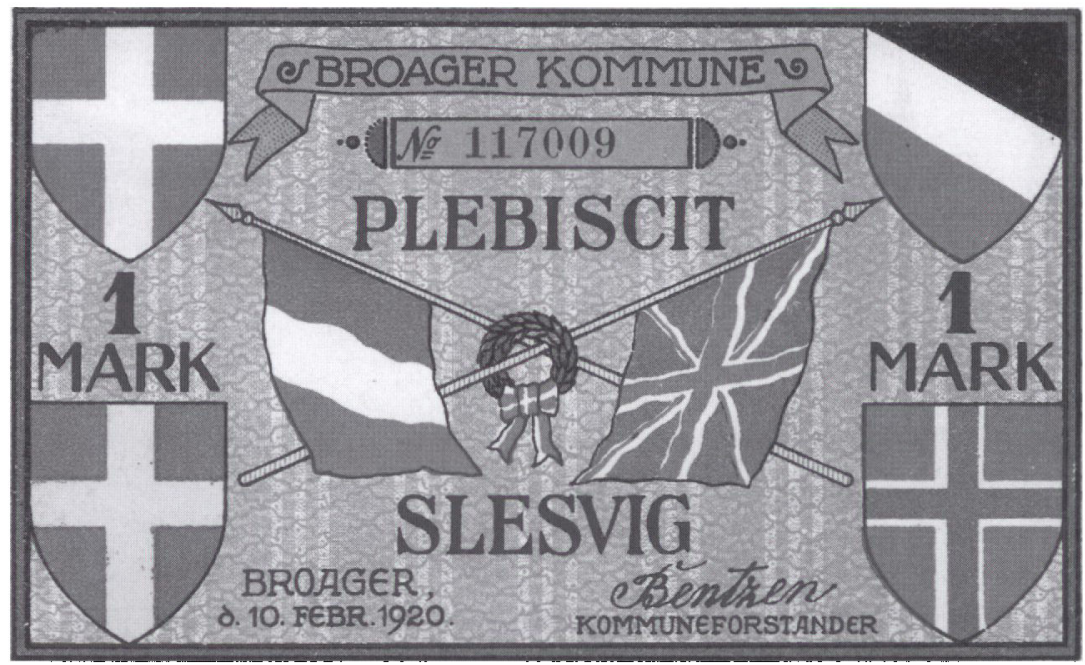

Nødpengeseddel. Nødpengesedler var $i$ omløb $i$ hele Tyskland fra 1913. Den 20. maj 1920, da kronemonten blev indført, blev brugen af nødpengesedler forbudt $i$ Nordslesvig.

ganda fra både dansk og tysk side. Den almindelige forekomst af nødpengesedler gav også anledning til forsøg på falsknerier. Ved at sælge falske sedler $\mathrm{i}$ egne langt fra de påførte udstedelseskommuner kunne falskneren tjene gode penge. Den 18. maj 1920, to dage inden kronemøntens indførelse $\mathrm{i} 1$. zone, blev brugen af nødpengesedler forbudt ved af den internationale kommission, og de mistede deres brugsværdi. ${ }^{15}$

\section{Kronelån og valutaspekulation}

Den samlede prioritetsgæld i 1914 var cirka på 220 millioner mark. Markkursens fald gav nu mulighed for at afvikle gælden på favorable vilkår. Fra sidst i 1918 begyndte flere og flere, kulminerende i efteråret 1919, at optage kronelăn i Danmark, for med denne mere værdifulde valuta at afvikle markgælden. Hjørnestenen i transaktionerne var en fast tro på, at den tyske Reichsmark før eller siden ville genvinde sin styrke. Det gjaldt derfor om at afvikle markgælden i tide, mens kursen stadig var lav. Til stort set alles overraskelse kom denne genrejsning af markens kurs aldrig.

Kronelånene fik stor betydning for valutaspørgsmålet. Spørgsmålet 
var, hvorledes der skulle tages hensyn til kronelånene i valutaordningen. Gældsafviklingen foregik ikke kun med hensyn til gæld ved de kielske kreditforeninger, men også internt i Nordslesvig. Der sad kreditorer tilbage i Nordslesvig med en langt mindre indfrielse, end hvad de havde udlånt før krigen. Dertil kom at den kronegæld, der var blevet skabt for at kunne afvikle markgælden, blev dyrere, efterhånden som genforeningen trak ud, hvorved den først opnåede fordel svandt ind. For at komme til bunds i denne sag besluttede den danske regering, på initiativ af det midlertidige ministerium for sønderjydske anliggender, den 18 . december 1919 at nedsætte et udvalg, der skulle undersøge disse forhold. Udvalgets navn var "Udvalget for Afhjælpning af de med Kronemøntens Indførelse i Sønderjylland forbundne Vanskeligheder", i daglig tale kaldt "Sønderjydsk Kroneudvalg«.

Udvalget havde tre opgaver at løse, hvoraf den første var at foretage en nøje Undersøgelse af, hvor mange og hvor store Kronelaan Sønderjyderne har optaget her $i$ Kongeriget og under hvilke Former og paa hvilke Vilkaar, de er optagne. ${ }^{16}$ Udvalgets to andre opgaver, dets sammensætning og rolle i valutasporgsmålet vil vi vende tilbage til senere, her skal vi koncentrere os om kronelånene. Den 16. marts 1920 kunne udvalget meddele det sønderjydske ministerium, at det statistiske materiale var tilvejebragt. Kronelånene udgjorde omtrent 60 millioner kroner, og langt den største part var anbragt i form af tre måneders veksler. Et veksellån er på nudansk et kortfristet lån. Udvalget kunne yderligere oplyse, at mange af lånene ville forfalde i løbet af de næste måneder, det vil sige marts, april, maj 1920. Udvalget ville forsøge at få lånene midlertidigt prolongerede eller forlængede, således at ingen kom i økonomiske vanskeligheder ad den vej. Det statistiske materiale var blevet tilvejebragt via spørgeskemaer til samtlige 411 danske pengeinstitutter.

Den realiserede driftskapital havde i løbet af krigen forstørret pengemængden i Nordslesvig. Markgældens indfrielse betød, at pengemængden blev endnu større. De frigjorte likvide midler skulle anbringes et sted, og her var de nordslesvigske pengeinstitutter første instans. Indskuddene i de nordslesvigske pengeinstitutter steg nærmest eksplosivt i krigens sidste år og i overgangstiden 1918 til 1920. Med kronelånene i Danmark afvikledes gæld til både kreditforeningerne, sparekasser og private kreditorer. Omtrent to tredjedele af sparekassernes hypoteklån blev indfriet i løbet af 1919. De tidligere kreditorer 


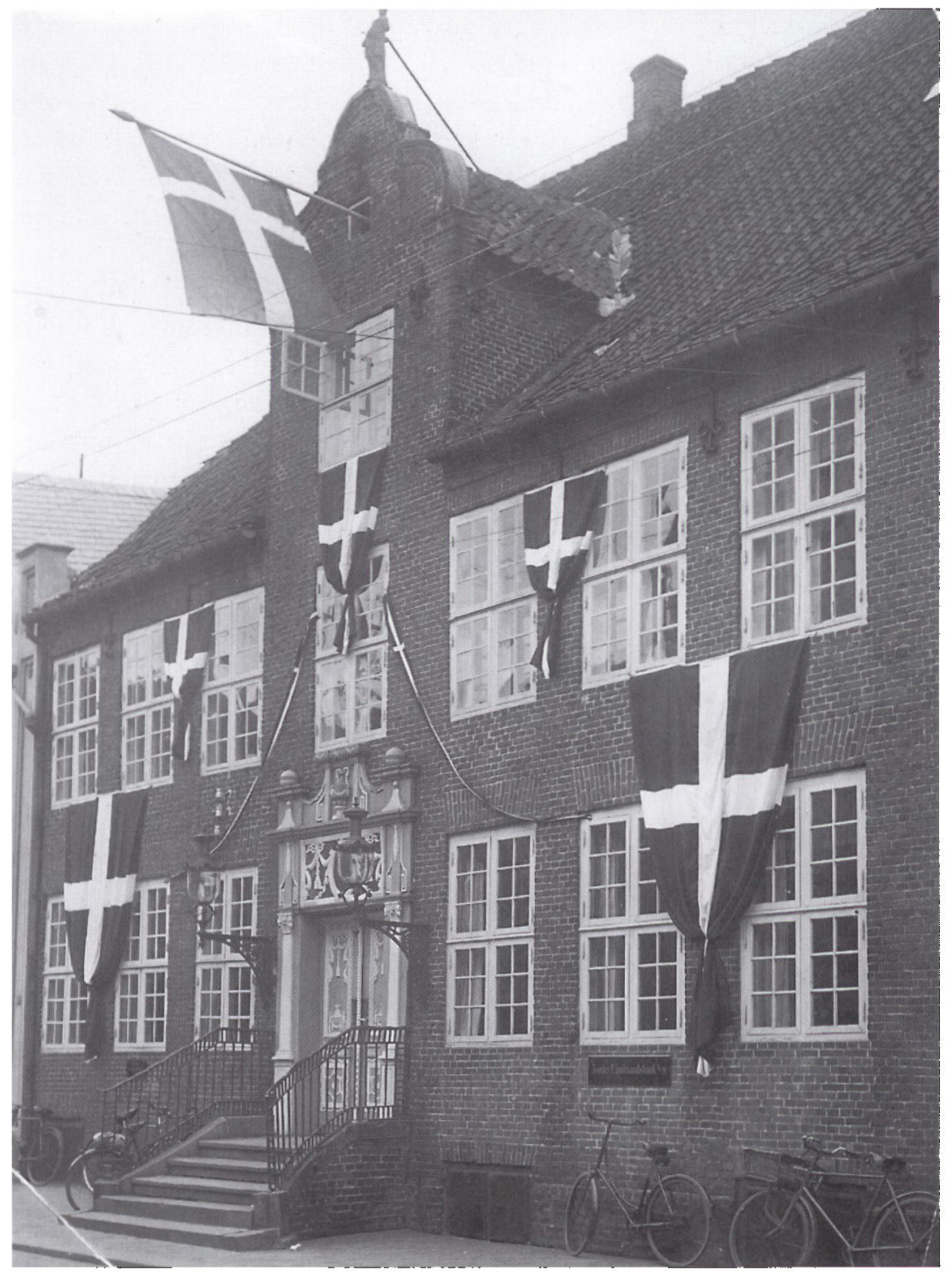

Tonder Landmandsbank angiveligt den 12. juli 1920, da Christian X red ind $i$ byen. Tonder Landmandsbank, en af de fire store nordslesvigske banker, blev stiftet den 30. september 1901. Den 15. juli 1970 fusionerede banken med Den Nordslesvigske Folkebank, Graasten Bank og Folkebanken for Als og Sundeved til Sydbank. Foto: Tønder Lokalhistoriske Arkiv. 
indsatte som regel deres nyindfriede kapital i sparekasser og banker. Bankindskuddene øgedes også af midler sydfra. Kapitalflugten fra Tyskland tog til i 1919 på grund af et øget skattetryk, og Nordslesvig var et af de steder kapitalen gik hen. ${ }^{17}$ Sparekasserne anbragte en del af deres midler i bankerne, men i sommeren 1919 måtte bankerne stoppe disse indskud. Både sparekasser og banker måtte herefter lade de overskydende midler gå sydpå, som indskud i tyske storbanker, værdipapirer eller som lån til tyske kommuner. ${ }^{18}$

Troen på en genrejsing af markkursen var ikke kun et nordslesvigsk fænomen, den fandtes i finanskredse verden over. I frisk erindring stod en til guldet bundet stabil Reichsmark og en betydelig økonomisk fremgang for det tyske rige siden 1870 'erne. Det var ganske enkelt utænkeligt, at den tyske rigsbank skulle miste kontrollen over den monetære situation. Fakta var, at det havde den allerede gjort ved krigsudbruddet $i$ august 1914.

\section{Valutaspørgsmålet rejses}

Da Nordslesvigsk Vælgerforenings tilsynsråd i dagene den 16-17. november 1918 udformede Aabenraa-resolutionen, nedsatte vælgerforeningen samtidig en række udvalg til at forberede genforeningens lovbestemmelser. Det drejede sig om et skoleudvalg, et kirkeudvalg, et økonomisk udvalg og et overordnet aktionsudvalg. Det okonomiske udvalg skulle beskæftige sig med »agrariske og finansielle spørgsmål ved overgangen «, herunder valutaspørgsmålet. Formand for det økonomiske udvalg blev medlem af den preussiske landdag H.D. Kloppenborg-Skrumsager, og P. A. Callø blev sekretær. Det økonomiske udvalg holdt konstituerende møde lørdag den 30 . november 1918 , og her inddeltes udvalget $\mathrm{i}$ fem underudvalg for henholdsvis landbrug, handel, industri, håndværk og finansvæsen. De forskellige nordslesvigske brancheorganisationer skulle selv udpege repræsentanter til disse underudvalg. ${ }^{19}$ Underudvalget for finansvæsenet fik en slags overordnet rolle for de fire andre underudvalg. De fire underudvalg for landbrug, handel, industri og håndværk fik til opgave at udarbejde betænkninger vedrørende det pågældende erhvervs stilling og onsker i samarbejde med erhvervets organisationer. Ud fra disse betænkninger fik underudvalget for finansvæsenet til opgave at udarbejde et forslag til valutareguleringen i samarbejde med repræsentanter for de nordslesvigske banker og sparekasser ${ }^{20}$ Denne ar- 
bejdsfordeling medførte, at de nordslesvigske banker og sparekasser fik en ganske stor indflydelse på det forslag til valutareguleringen, der skulle stilles fra Nordslesvigsk Vælgerforening. Så meget desto mere som både direktøren for Haderslev Bank, Christian Hübbe og bogholder ved Frøs og Kalvslunds Herreders Sparekasse, P. A. Callø, samt direktørerne for Nordslesvigsk Kreditforening Marten Refslund Poulsen og J.H. Schmidt sad i finansudvalget.

\section{Kriegerudvalget}

At den danske regering i december 1918 også påbegyndte praktiske forberedelser til genforeningen, var alene H.P. Hanssens fortjeneste. På et møde med den danske regering den 3. december 1918, foreslog H.P. Hanssen regeringen at nedsætte et for genforeningen forberedende udvalg. Dette forslag blev fulgt, også med hensyn til Hanssens forslag om at lade herredsfuldmægtig i Stege, Martin Hammerich, udpege som udvalgets sekretær. Martin Hammerich fik med tiden en meget central rolle $\mathrm{i}$ den praktiske gennemførelse af genforeningen. Kongens kabinetsekretær, A. Krieger, blev formand for "Sønderjysk Udvalg af 1918«, hvorfor udvalget i daglig tale hed »Krieger-udvalget«. Udvalget bestod kun af de to og skulle operere på fortrolig vis for ikke at provokere Tyskland. Statsminister Th. Zahle deltog sammen med H.P. Hanssen i udvalgets første møde den 16. december 1918, hvor udvalgets arbejdsområder drøftedes.

Statsminister Zahle havde den opfattelse, at Kriegerudvalget blot skulle stå til rådighed for sønderjyderne ved at svare på spørgsmål fra vælgerforeningens nedsatte udvalg. På mødet den 16 . december opfordrede Krieger Hammerich til at udfærdige en betænkning over de eventuelle problemer, han så ved indlemmelsen af Nordslesvig, samt at undersøge eventuelle fortilfælde. Denne betænkning havde Hammerich klar den 27. december, og betænkningen giver et godt indblik i Hammerich's opfattelse af udvalgets rolle og genforeningens største praktiske problemer.

Omkring de praktiske problemer ved genforeningen udskilte Hammerich først de traktatmæssige spørgsmål, der skulle løses ved fredskonferencen, og som udvalget ikke skulle beskæftige sig med. Finansielle mellemværender mellem Danmark og Tyskland hørte hertil. Det var spørgsmål om overtagelse af en del af Tysklands statsgæld, af tyske statsejendomme og pensionsforpligtelser, dokumenter og arki- 


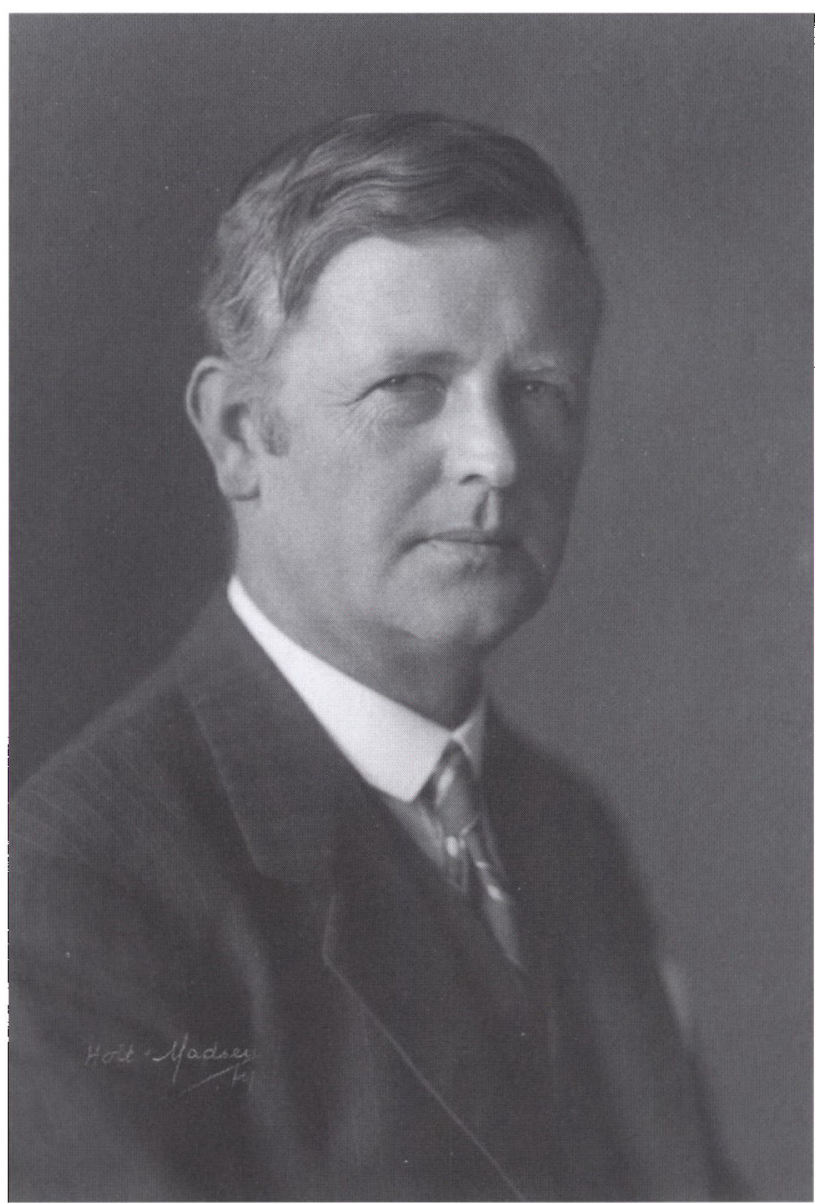

Martin Hammerich (1883-1940). Sekretær for "Krieger-udvalget", der blev nedsat $i$ december 1918 for at forberede den praktiske side af genforeningen. I maj 1919 blev Hammerich kontorchef $i$ det midlertidige ministerium for sonderjyske anliggender. Martin Hammerich fik sammen med H.P. Hanssen meget stor indflydelse på valutasporgsmålets udvikling og losning. Foto: Institut for sønderjysk Lokalhistorie.

valier. Dernæst opstillede Hammerich et program bestående af 9 punkter angående indlemmelsen af Nordslesvig. Programmet var følgende:

1. Toldgrænsen må effektueres straks.

2. Dansk mønt må påbydes som betalingsmiddel.

3. Dansk mål og vægt indføres.

4. Overtagelse af postvæsenet.

5. Overtagelse af telegrafvæsenet.

6. Overtagelse af statsbanerne. 
7. Dansk administrativt system indføres.

8. Kommunalforvaltningen ordnes efter dansk system.

9. Dansk kirkesystem indføres.

Hammerich anså det for vigtigt, at Nordslesvigs tilknytning til Danmark markeredes så hurtigt som muligt. Det var en fordel praktisk, men også af symbolsk værdi. Det er i det lys at Hammerichs 9-punkts program for indlemmelsen skal ses. At Hammerich som punkt nummer et $\mathrm{og}$ to anfører flytning af toldgrænsen og indførelsen af danske kroner viser, at valutareguleringen blev prioriteret højt af Kriegerudvalget. Kronemøntens indførelse var et klart symbol på Nordslesvigs tilknytning til Danmark. Det betød også, at udvalget før eller siden måtte tage initiativ med hensyn til indførelsen.

På tre områder kunne det ifølge Hammerich blive nødvendigt med særlove. For det første for at forhindre ejendomsspekulation i Nordslesvig. For det andet ved aflastning af kommuner og kredses krigsgæld. Og for det tredje omkring valutaspørgsmålet. I visse tilfælde kunne lovgivningen indføres gradvist, således at tyske love kunne fungere i en overgangsperiode. Det gjaldt blandt andet skatte-, patent- og sociallovgivningen. Ellers måtte hele det danske lovsystem indføres på en gang. Betænkningen afsluttes med en bemærkning om, at udvalget straks ville påbegynde forberedelsen af forslag til Nordslesvigs inddeling i amter og kommuner. Af betænkningen fremgår det, at Krieger hovedsagelig var enig i Hammerich's overvejelser. Krieger mente desuden, at det først og fremmest var det administrative apparat, der skulle forberedes. ${ }^{21}$

Selvom kronemøntens indførelse stod højt på Hammerich's liste, var det således ikke valutaspørgsmålet, Kriegerudvalget koncentrede sig mest om. Det var det administrative område, der var udvalgets vigtigste. Men Hammerich satte valutaspørgsmålet på dagsordenen, som en vigtig del af genforeningen og som et område, hvor en særlov kunne blive nodvendig.

Da Kriegerudvalget kom til møde på statsminister Zahles kontor den 31. december 1918, accepterede Zahle Hammerichs betænkning angående Kriegerudvalgets arbejdsområder. Zahle kunne tilføje, at overgangstiden måtte gøres så kort som muligt, og at landsdelen på ingen måde måtte få en særstilling $i$ forhold til resten af landet. ${ }^{22} \mathrm{De}$ synspunkter var Zahle ikke ene om, og de var et gennemgående træk ved den officielle rigsdanske holdning til genforeningsprocessen. 


\section{Mødet $i$ København den 22. januar 1919}

Første gang Kriegerudvalget berørte valutaspørgsmålet, var da H.D. Kloppenborg-Skrumsager den 18. januar 1919 bad udvalget om at arrangere et møde mellem økonomisk sagkyndige personer fra Danmark og vælgerforeningens finansudvalg, for at sondere valutaspørgsmålets stilling i de kredse. Mødet berammedes til onsdag den 22. januar 1919 på Kriegerudvalgets kontor i "Hotel Kongen af Danmark «s bygning på Holmens Kanal i København. Det var en række af Danmarks fremmeste økonomiske eksperter, som vælgerforeningens finansudvalg stod overfor på dette møde. Det drejede sig om nationalbankdirektør Marcus Rubin, departementschef $\mathrm{i}$ finansministeriet og statsgældsdirektør P.O. A. Andersen, professor i nationaløkonomi Axel Nielsen, professor i samme og folketingsmand for det konservative folkeparti L. V. Birck, redaktør for Finanstidende Carl Thalbitzer, Niels Neergaard fra Venstre og den socialdemokratiske borgmester Jens Jensen, København. Fra vælgerforeningens økonomiske udvalg var ud over finansudvalget også formanden H.D. KloppenborgSkrumsager til stede.

Christian Hübbe udlagde på mødet den holdning til valutaspørgsmålet, som udgik fra et flertal i det økonomiske udvalg og de nordslesvigske erhvervsorganisationer. En omveksling af hele den nordslesvigske markbeholdning, både gæld, tilgodehavender, indeståender og kontanter, til parikurs, 89 kroner for 100 mark, var et krav for at nordslesvigerne kunne jævnstilles med det danske folk. Det var en løsning der klart var $\mathbf{i}$ kreditorernes interesse, og ikke mindst $\mathbf{i}$ landbrugets interesse, jævnfør den generelt forøgede likviditet. Da markkursen i januar 1919 var nede på 46,3 kroner for 100 mark, ville en sådan ordning allerede på det tidspunkt koste den danske stat et betydeligt beløb.

Udtalelserne fra de økonomisk sagkyndige danskere viste med al tydelighed, at nordslesvigerne ikke skulle regne med en ubetinget finansiel støtte fra Danmark i forbindelse med kronemøntens indførelse. Grundige undersøgelser af hver eneste nordslesvigers økonomi måtte gå forud for en eventuel økonomisk støtte fra den danske stat. Helt afgørende var det, at flere af det nordslesvigske finansudvalgs medlemmer bekræftede dette forhold. P.A. Callø, Marten Refslund Poulsen og J.H. Schmidt fremhævede alle de meget brogede økonomiske forhold, der var opstået i Nordslesvig under krigen. Særligt 
Edvard Brandes (1847-1931), finansminister $i$ regeringen Zahle fra 1913 til 1920.

Som sådan udstak han dagsordenen for det nordslesvigske valutasporgsmåls løsning. Edvard Brandes var en kontroversiel skikkelse i mange henseender, således også med sin markante uvilje mod en storre økonomisk stotte til Nordslesvig $i$ forbindelse med genforeningen. Foto: Det kongelige Bibliotek.

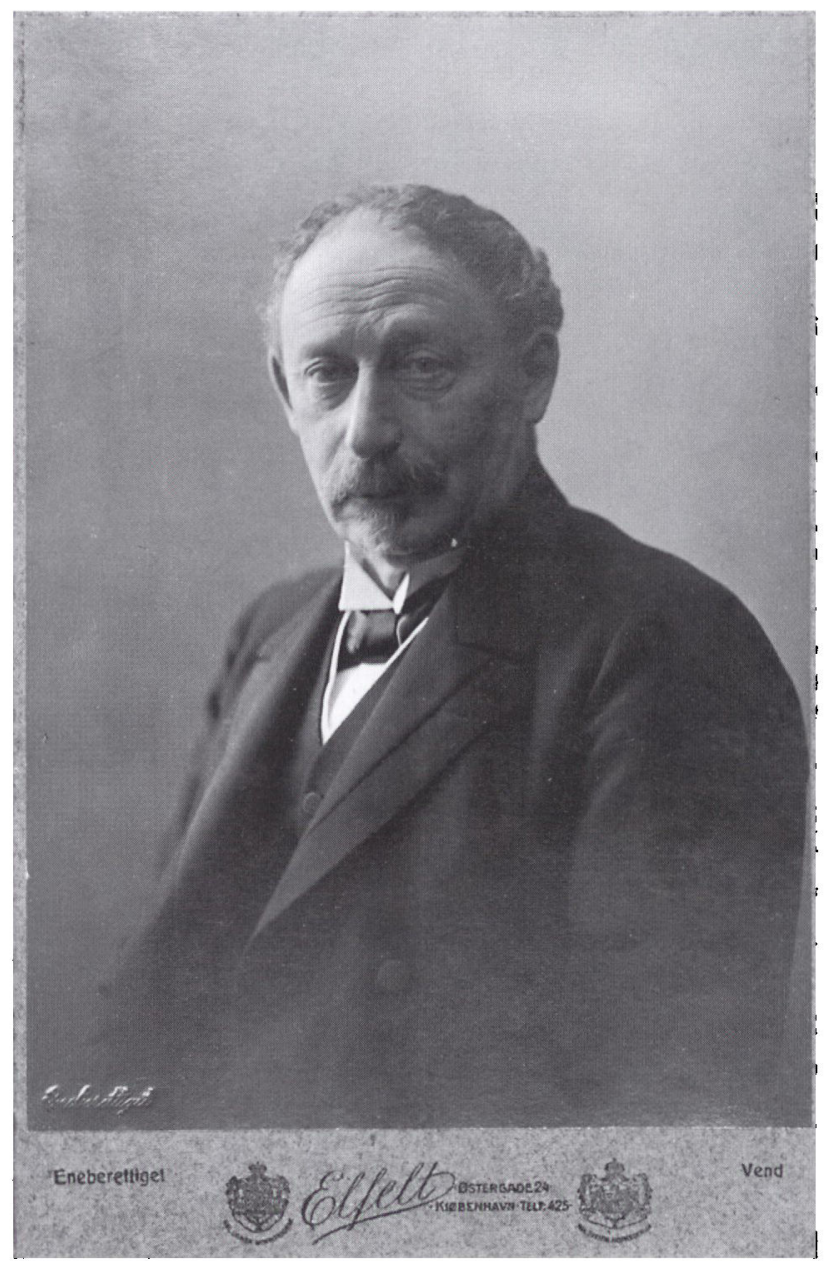

mente de, at det nordslesvigske landbrug stod godt økonomisk og ikke havde behov for økonomisk hjælp. Callø, Schmidt og Refslund Poulsen mente desuden, at de nordslesvigske debitorer selv burde dække kreditorernes tab. Det var ikke den danske stats ansvar.

Nordslesvigerne måtte tage hjem uden nogen konkrete løfter fra kongeriget. Dertil havde de tilstedeværende rigsdanskere heller ikke mandat. De tanker, der blev født på mødet, og som skulle hænge ved valutaspørgsmålet under hele processen, var et forslag om individuelle undersøgelser af nordslesvigernes økonomi og et forslag om en 
statslig kasse, der skulle stå for valutareguleringen. Niels Neergaard havde ikke blandet sig meget $i$ debatten. Den ene gang han luftede sin holdning, var det til forsvar for de nordslesvigske småkreditorer, der efter hans mening nødvendigvis måtte hjælpes af staten.

Noget kunne således tyde på, at det var fra dette politiske hold, at nordslesvigerne kunne regne med størst velvilje. I den forbindelse er det bemærkelsesværdigt, at der ikke var deltagere fra regeringen til stede. Kun finansministerens departementschef repræsenterede regeringen. Finansminister Edvard Brandes' egen tilstedeværelse havde ellers været naturlig i dette selskab. Det var hovedsagelig nationalokonomiske eksperter, der var til stede. Problemet ved dette forhold var, at det ikke var disse eksperter, men politikere fra rigsdagen, der i sidste ende skulle bevilge en økonomisk støtte til Nordslesvig. De lidet konkrete løfter og mangelen på mandat hos de rigsdanske personer betød, at nordslesvigerne misfortolkede de udtalelser, der var fremkommet på mødet, som brede løfter om økonomisk hjælp til Nordslesvig.

\section{Det økonomiske udvalgs betænkning}

Den 30. april 1919 fremlagde vælgerforeningens økonomiske udvalg en betænkning om valutaspørgsmålet. ${ }^{23}$ Betænkningen var først og fremmest præget af, at mange forskellige nordslesvigske interesser kom til orde.

I betænkningen henviste det økonomiske udvalg forst til, at en omveksling til dagskurs, som på dette tidspunkt var omkring 31 kroner for 100 mark, ville ruinere mange nordslesvigere. Herefter blev de fire underudvalgs betænkninger omtalt hver for sig. Handelsudvalget ønskede, at valutareguleringen skulle forgå til fredskurs for at tage hensyn til handelsstandens realisering af driftskapitalen, der var en følge af varemangelen. Håndværkerudvalget mente derimod, at en omregning til dagskurs var bedre, idet mange håndværkere allerede havde optaget nye lån for at genrejse deres virksomheder. Man var dog klar over, at der ikke udelukkende skulle tages hensyn til håndværkerne, men at der måtte findes en løsning, der tog hensyn til hele den sønderjyske befolknings tarv. Industriudvalget henviste til erhvervets tomme lagre, og til at den frigjorte kapital ikke ville kunne fylde disse, medmindre en omveksling til fredskurs fandt sted. Landbrugsudvalget mente, at en omregning til fredskurs eller så nær den- 
ne som muligt var eneste mulighed. Også her var den realiserede kapital begrundelse.

På baggrund af disse fire betænkninger var udvalget den 7. marts efter forhandlinger blevet enige om fem krav til valutareguleringen. For det første måtte kursreguleringen foregå ved en omregning af gæld og tilgodehavender til en forbedret kurs, helst fredskursen. For det andet blev et statsligt institut foreslået oprettet med midler til at gennemføre valutareguleringen. Dertil skulle et nævn knyttes bestående af upartiske lokalt sagkyndige mænd, som skulle foretage individuelle undersøgelser af nordslesvigernes økonomi. Instituttet skulle autoriseres til at ombytte den nordslesvigske markbeholdning til kroner. For det tredje skulle nordslesvigske tilgodehavender syd for det afståede område overtages af instituttet. For det fjerde skulle reguleringen forbindes med en skat på valutatransaktioner foretaget før omvekslingen, og for det femte måtte tysk kapital udelukkes, hvorimod kapital nordfra kunne omregnes til den fastsatte kurs.

Ud fra disse fem krav havde det økonomiske udvalgs finansudvalg udarbejdet et forslag til valutareguleringen. Dette forslag havde finansudvalget afleveret til Kriegerudvalget den 21. marts. Ganske overraskende havde finansudvalget valgt at se bort fra det første krav om omveksling af gæld og tilgodehavender til fredskurs. Gæld og tilgodehavender kunne ikke omveksles til samme kurs. Begrundelsen var, at mange debitorer allerede havde afviklet deres gæld fordelagtigt, og at de tilbagestående debitorer ikke skulle afskæres fra denne mulighed. Hvilken kurs der så skulle gælde var ikke nævnt. Det kan undre, at finansudvalget kunne se bort fra et krav, der var opnået flertal for i det samlede økonomiske udvalg, og som efterfølgende blev trykt i udvalgets betænkning.

\section{Diskussionen om det økonomiske udvalgs dispositioner}

Flere af det økonomiske udvalgs medlemmer tog efterfølgende afstand fra udvalgets krav. Marten Refslund Poulsen, der sad i finansudvalget, skriver i sine erindringer om sit medlemskab af det økonomiske udvalg:

Jeg var lidet stolt af det Medlemskab. Vel sagde jeg ved Droftelserne før Vedtagelserne af Indstillingerne, at vi burde være noget mere beskedne $i$ vore Krav, men jeg havde ikke Fasthed nok til at komme med en Mindretalsindstilling, for jeg var saa kommet til at ride alene. Da de andre fremhævede 


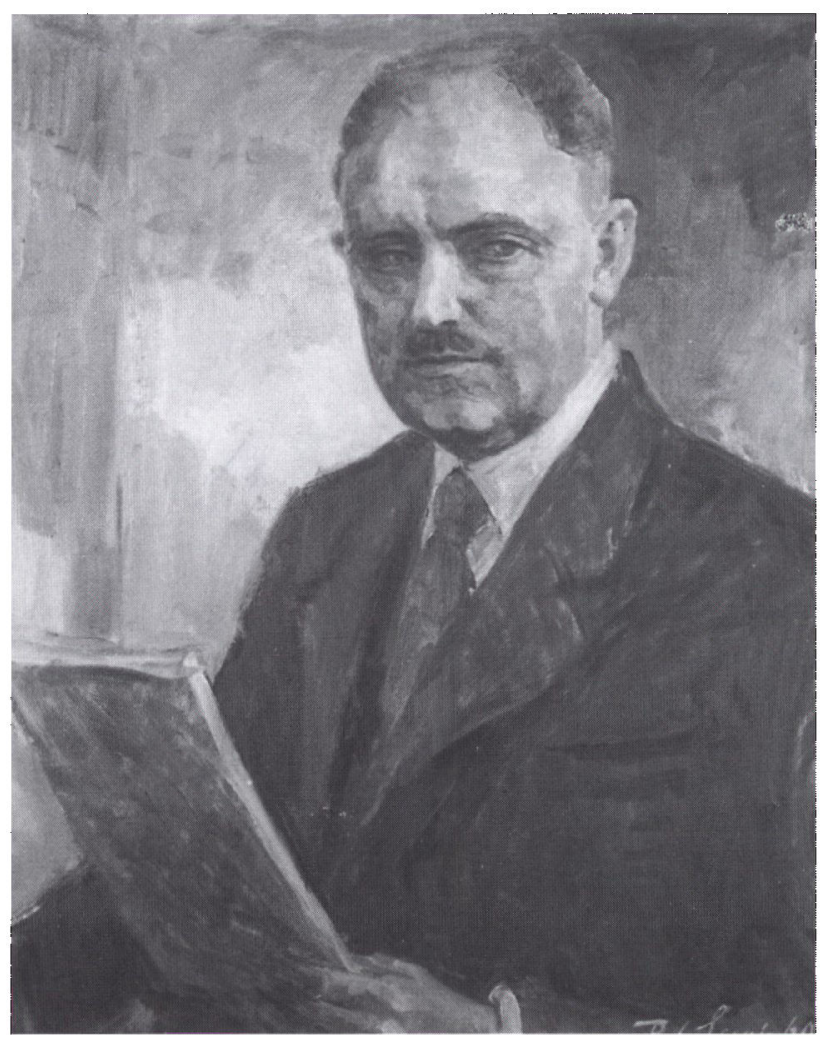

P. A. Calle (18821960). Direkter for Sønderjyllands Kreditforening 1920-1960.

P.A. Callo var en meget aktiv skikkelse $i$ valutasporgsmálet 191820. Tidligt i forlobet indsa han, at erstatningsprincippet var uomgængeligt $i$ valutasporgsmålets lasning, og at det var erstatningsbelobenes starrelse og omfang der skulle forhandles om. Foto: Institut for sønderjysk Lokalhistorie.

Betydningen af, at Indstillingerne var enstemmige, gav jeg mig. Vi var saa umaadeholdne $i$ vore Krav til Danmark, at vi fik mindre Indflydelse, end hvis vi havde været rimelige. ${ }^{24}$

P. A. Callø tog også senere forbehold over for udvalgets aktiviteter. Således skriver han om udvalget i 1922: Jeg var bleven udset til Sekretær for det økonomiske Udvalg, men jeg maa sige, at det ikke er med Glæde jeg ser tilbage paa dets Virksomhed. Det Spørgsmaal, som optog Sindene mest og beherskede Forhandlingerne i Udvalget, var Valutaproblemet. Det økonomiske Udvalg har ikke givet noget positivt Bidrag til Losningen af dette vanskelige og for vor Landsdel saa vigtige Sporgsmaal. ${ }^{25}$ Hvorvidt der er tale efterrationaliseringer kan altid diskuteres. Det er værd at bemærke, at Refslund Poulsen og Callø på mødet i København den 22. januar begge havde nævnt, at landbruget ikke behøvede direkte støtte. Begge sad de dog også $i$ det finansudvalg, der afgav forslag til en 
valutaregulering. I dette forslag blev der netop set bort fra kravet om en omregning til fredskurs for gæld og tilgodehavender med begrundelse $i$, at debitorerne allerede havde afviklet deres markgæld fordelagtigt. Refslund Poulsen og Callø var således gået uden om flertallet i det økonomiske udvalg og havde gjort deres indflydelse gældende gennem finansudvalget.

Christian Hübbe forsvarede til gengæld det økonomiske udvalgs krav efter genforeningen. I 1925 mente Hübbe, at kravet om en omveksling til fredskurs var rimelig, da gældsafviklingen endnu ikke havde nået det store omfang i april 1919. Det var først i løbet af efteråret 1919, at forholdet mellem debitorerne og kreditorerne havde ændret sig så meget, at det ikke længere var muligt at ordne valutaspørgsmålet ved en kursregulering. Både Hübbe og Callø fandt således debitorernes afvikling af gæld forkastelig, da det efter deres mening ødelagde en ordentlig og retfærdig valutaregulering. ${ }^{26}$

Kriegerudvalgets møde med finansministeren 25-26. marts 1919

Den 25. og 26. marts 1919 var Kriegerudvalget til møde hos finansminister Edvard Brandes, hvor også udenrigsminister Scavenius, etatsråd og direktør for Landmandsbanken Emil Glückstadt, nationalbankdirektør Rubin, samt departementscheferne for henholdsvis Udenrigs- og Finansministeriet var til stede. På mødet blev valutaspørgsmålet drøftet, og i denne drøftelse udtalte finansministeren, at han mente at være udrustet til at kunne bevilge 50 eller 100 millioner kroner samtidig med genforeningen. Denne bevilling kunne stilles til rådighed for valutaordningen på den måde, der syntes mest hensigtsmæssig og retfærdig. Hvilke principper, der skulle anvendes, syntes efter Hammerichs opfattelse ikke at være afklaret. ${ }^{27}$ Det var således lidet konkret, hvad Finansministeriet havde af planer indtil videre.

Etatsråd Glückstadt var blevet udnævnt til den danske regerings repræsentant i finansielle spørgsmål ved fredskonferencen i Paris. Glückstadt afleverede på mødet et udkast til løsning af det nordslesvigske valutaspørgsmål. Glückstadts forslag var et eksempel på en kursreguleringsløsning, hvor eksisterende formuer under 50.000 mark skulle omveksles efter en glidende kursskala. Individuelle undersøgelser måtte foretages forud for reguleringen således, at der ikke blot blev reguleret over en kam. Det skulle blive et bærende princip 
i valutaordningen, men ikke $i$ form af en kursregulering af 1920-formuer.

Samme dag, den 26. marts, læste Martin Hammerich et af ham udfærdiget udkast om valutaspørgsmålet op. Hammerich stillede indledningsvis spørgsmålet, om sønderjyderne havde et moralsk krav på en kursregulering opad, eventuelt til fredskurs? Hertil svarede Hammerich selv:

Er Forholdet ikke at hvis Sonderjyderne var blevet ved Tyskland ville Markkursen efter al Sandsynlighed være det sande Udtryk for Markens Kobeevne i Forhold til Kronens? Markens Ombytning med Kroner efter Dagskurs vil herefter ikke betyde nogen Formueforringelse for Markejere. Argumentationen er noget hypotetisk, men afspejler en grundholdning hos Hammerich. De økonomiske trængsler, Nordslesvig stod i, var forårsaget af eksterne faktorer forbundet med Tyskland. Overgangen til Danmark var i sig selv en økonomisk fordel for Nordslesvig i sammenligning med at blive under Tyskland. Nordslesvig skulle derfor ikke regne med at få okonomisk kompensation for overgangen til Danmark, men kun til at afhjælpe krigens belastninger. Hammerich fremlagde også et forslag til valutareguleringen. Alle burde kunne ombytte et mindre beløb, for eksempel 200 mark, til samme beløb i kroner. Derudover måtte en kursregulering finde sted. Dertil måtte formuer pr. 1. oktober 1918 lægges til grund, og formuer over 70.000 mark udelukkes. Et beløb på 10.000 mark kunne reguleres efter fredskurs, 89 kroner for 100 mark, for så vidt et sådant beløb fandtes 1 . oktober 1918, enten i kontanter, indskud, papirer eller tilgodehavender. Beløb over 10.000 mark kunne reguleres efter en glidende skala, men ingen formuer måtte ved reguleringen komme over 70.000 mark. De, der ønskede regulering, skulle udfylde et skema med alle relevante oplysninger og et nævn nedsættes, der kunne efterprøve de enkelte sager. Formueopgørelsen skulle således gå tilbage til oktober 1918 og ikke indeholde formuer opstået efter dette tidspunkt. Det var tabene som følge af krigen, der skulle erstattes, og ikke andet. Det princip skulle blive bærende for valutaordningen.

Betegnende for den danske centraladministrations holdning til valutaspørgsmålet var Kriegerudvalgets anmodning til finansminister Brandes om at overveje, hvad der kunne gøres for at dæmpe sønderjydernes forventninger til en kommende valutaregulering. Finansministeren mente, at det ville være vanskeligt at komme med en offentlig udtalelse om dette, men ville være opmærksom på sagen. 
Brandes' skepsis er forståelig, da regeringens stilling i grænsespørgsmålet i forvejen var skrøbelig. En udtalelse om, at sønderjyderne ikke skulle forvente den store økonomiske hjælp, ville ikke styrke regeringens position $\mathrm{i}$ den henseende.

Møderne den 25. og 26. marts i Finansministeriet vidner om en mere end forbeholden rigsdansk stemning over for en ubetinget økonomisk hjælp til nordslesvigerne. Det var klart, at der ville blive stillet mange flere krav til hjælpen, end de fleste nordslesvigere forestillede sig.

\section{Nordslesvigske divergenser og tysk agitation}

Den noget diffuse betænkning, Vælgerforeningens økonomiske udvalg havde udformet, var et tegn på, hvor svært det var at udforme et enstemmigt forslag i Nordslesvig. I tiden efter betænkningens udgivelse blev de divergerende meninger blandt nordslesvigerne mere tydelige, og samtidig fik valutaspørgsmålet også pressens bevågenhed. Allerede i marts 1919 havde Sønderjydsk Arbejderforening stillet forslag om en glidende skala, hvor kun de første 5.000 mark omveksledes til fredskurs. Det var et langt mindre krav end det, der blev fremsat i det økonomiske udvalgs betænkning.

På samme dag som det økonomiske udvalgs betænkning udkom, den 30. april 1919, bragte Aabenraa-avisen Hejmdal en artikel om valutaspørgsmålet. Artiklen var indsendt af en anonym undertegnet Aø. Artiklen skulle blive starten på en større nordslesvigsk avisdebat, der varede det meste af sommeren 1919. Skribentens forslag var, at debitorerne betalte deres del af reguleringen. Da debitorerne allerede var i gang med at afvikle deres gæld, ville en beskatning af debitorernes gevinster være rimelig, ifølge skribenten. Med hensyn til reguleringen ville en almindelig benyttelse af fredskursen ikke være mulig, da mulighederne for at udnytte en sådan ordning ville blive meget stor. Ifølge skribenten måtte reguleringen derfor ske efter en glidende skala, hvor i hvert fald de første 10.000 mark omveksledes til fredskurs. Ældre mennesker måtte have indtægtstilskud til deres renteindtægter, mens erhvervslivet skulle gives gode lånemuligheder. ${ }^{28}$

Artiklen gav anledning til en række svar, som alle forsvarede kravet om omveksling til fredskurs bravt. ${ }^{29}$ Et helt andet forslag kom fra Th. Kaufmann fra Bovrup, der sad i det økonomiske udvalgs underudvalg for håndværket. Kaufmann mente, at omregningen ganske enkelt kunne vente til markkursen igen havde rettet sig. Det eneste, der 
skulle iværksættes fra den danske stat, var en midlertidig afviklingskasse, hvor der kunne veksles mark til kroner ved dagskurs. ${ }^{30}$

Valutaspørgsmålet indgik også i den nationale propaganda fra både tysk og dansk side. Deutscher Ausschuß für das Herzogtum Schleswig var blevet dannet i Flensborg den 31. oktober 1918. Udvalget var ment som en samlet tysk organisation $i$ kampen for at bevare et tysk Nordslesvig. Deutscher Ausschuß benyttede sig i sin argumentation af den manglende udmelding fra den danske regering om valutaspørgsmålet. Det blev fortolket som en afvisning af nordslesvigernes krav, hvad der var en vis grad af sandhed i. Til gengæld var der mindre sandhed i fortolkningen af, hvad valutaordningen i stedet ville medføre. En typisk tysk argumentation findes i Flensburger Volkszeitung den 11. juni 1919: Danach ist von einer Umrechnung der Markguthaben und der Markbestände zum Friedenskurs nicht die Rede. Nicht einmal eine Umrechnung zu einem verbesserten Zwangskurs haben wir zu erwarten. Die Umrechnung wird nur zum Tageskurs stattfinden. Das sind vernichtende Aussichten für die Schleswiger, die durch das Machtgebot unsere Feinden an Dänemark ausgeliefert werden sollen.

\section{Striden om H.P. Hanssens ministerpost}

Medvirkende til splittelsen i Vælgerforeningen var også, at $H$. P. Hanssen den 25. juni 1919 blev udnæunt til minister uden portefølje af den radikale Zahle-regering. H.P. Hanssen skulle lede det midlertidige ministerium for sønderjydske anliggender i overgangstiden og var udnævnt på grund af sin indsigt i nordslesvigske spørgsmål. Når udnævnelsen gav anledning til heftige angreb på H.P. Hanssen, hænger det sammen med den almene uvilje mod den radikale regering og mod H.P. Hanssens indtræden i det partipolitiske spektrum. H.P. Hanssen accepterede ministerposten, fordi han mente at tjene Nordslesvig bedst på denne måde. Det midlertidige ministerium for sønderjydske anliggender udførte $i$ dets tid et meget omfattende arbejde og var stort set medvirkende i hver eneste del af genforeningens praktiske ordninger. Med ministeriets oprettelse kunne Kriegerudvalget nedlægges og dets arbejde overføres til ministeriet. H.P. Hanssen forlangte samtidig, at Kriegerudvalgets sekretær Martin Hammerich blev ministeriets kontorchef.

Valutaspørgsmålet berøres sidste gang af Kriegerudvalget ved et møde tirsdag den 6. maj 1919 i Udenrigsministeriet, hvor samtlige 
ministre og administrationens højeste embedsmænd var til stede. På mødet blev alle de praktiske problemer omkring genforeningen og deres foreløbige behandling drøftet. Den største forhindring for en lempelig overgang var, som A. Krieger påpegede, usikkerheden om, hvornår Danmark var berettiget til at overtage administrationen. Finansminister Brandes kunne berette, at en fuldstændig plan for en flytning af toldgrænsen lå klar, men at intet sikkert kunne siges derom, førend den danske kompetence var kendt. Hvis toldgrænsen blev flyttet, måtte de offentlige kasser kunne modtage tysk mønt efter en bestemt omregningskurs, og også her lå et lovforslag klar. Finansministeriet havde tænkt sig at oprette en afregningskasse, hvor tysk mønt kunne føres hen og favorable lån gives til det nordslesvigske erhvervsliv. Endelig mente Brandes, at der måtte ydes økonomisk hjælp til Nordslesvig, men at også dette ville kræve en lov. ${ }^{31}$

\section{Finansministeriets første forslag}

Fra flere sider ventede man utålmodigt på et udkast fra finansministeren. Ved en folketingsdebat om en ændring af Nationalbankens oktroj, den 17. juni 1919, udtalte den konservative L. V. Birck:

Naar jeg taler om dette, er det fordi jeg gerne vil slå fast $i$ den offentlige Bevidsthed, at der er den Fare for dette Land, at Marken skal omklamre os og rive vore Kroner med, og jeg vil derfor være lykkelig om den højtærede Finansminister vil benytte denne Lejlighed til at sige, at alle Forventninger om, at vi skal indløse Slesvigernes Mark til Pari eller en anden Kurs er falske Forventninger, for ellers er der ingen grænse for hvor mange Mark der vil strømme til her. ${ }^{32}$

L.V. Birck frygtede, at kronens værdi ville falde betydeligt, hvis store mængder tyske mark skulle tilgå den danske stat. Det var ifølge Birck ikke blot statens finanser, der kunne skades ved en omveksling af nordslesvigernes mark til fredskurs, men også landets monetære situation. Finansministeren svarede Birck bekræftende den 19. juni i Folketinget. Den foreslåede omvekslingskurs ville blive dagskursen. En omregning til bedre kurser ville kun ske efter grundige forundersøgelser. ${ }^{33}$ Mere kunne finansministeren ikke afsløre på dette tidspunkt.

I april 1919 blev »Rigsdagspartiernes sønderjydske Udvalg« oprettet. Udvalget bestod af fem medlemmer fra hvert af rigsdagens partier. Dette udvalg skulle specifikt beskæftige sig med indlemmelsen af 
Nordslesvig, hvilket fremgik af det kommissorium, udvalget vedtog på sit konstituerende møde den 29. april 1919. Kommissoriet lød: Udvalgets opgave er uden besluttende Myndighed, som Mellemled mellem Rigsdagspartierne og Regeringen, at udøve en raadgivende Virksomhed ved Forberedelsen af den Lovgivning, som en eventuel Indlemmelse af Nordslesvig i Danmark vil nødvendiggøre. ${ }^{34}$

Onsdag den 30. juli 1919 fremlagde finansministeren det første forslag til en nordslesvigsk valutaregulering i Rigsdagspartiernes sønderjydske Udvalg. Det bestod af et lovforslag om indførelse af dansk mønt, et lovforslag om oprettelse af en afregningskasse og et lovforslag om en udligningskasse. De tre lovforslag indeholdt et par artige overraskelser for nordslesvigerne. Lovforslaget om kronemøntens indførelse gik i sin enkelhed ud på, at dansk møntlovgivning indførtes straks ved indlemmelsen, og at finansministeren bestemte omregningskursen for ind- og udbetalinger ved de offentlige kasser. Kursen fastsattes til dagskurs, ligesom betalinger mand og mand imellem skulle foregå ved dagskursen. Hertil tilføjede Brandes: Det kan nok være, at dette er en Skuffelse for mange $i$ Slesvig, men vi maa overhovedet regne med, at vi kommer til at skuffe visse Forventninger om, at der øjeblikkelig vil være pengelige Fordele ved Indlemmelsen. Vi er nødte at handle saaledes, som Statens Stilling kræver det. ${ }^{35}$

Forslaget om udligningskassen var et nyt element $\mathrm{i}$ diskussionen om valutareguleringen. Denne kasse skulle ifølge forslaget udstyres med 25 millioner kroner og yde hjælp til mindrebemidlede i det indlemmede område. Kassen skulle bestyres af et råd på 15 medlemmer fra Slesvig, der beskikkedes af finansministeren. Rådet skulle selv vælge formand og selv fastlægge principperne for sin virksomhed. Udligningskassens virksomhed skulle senest være afsluttet den 30 . september 1920. Brandes ville dog ikke stå inde for, at 25 millioner kroner var tilstrækkeligt.

Afregningskassen skulle fortrinsvis yde kronelån mod deponering af kontante markbeløb eller tilgodehavender i banker og sparekasser. Lånene kunne gives til dagskurs, således at nordslesvigerne kunne låne for det beløb, de deponerede $\mathrm{i}$ tyske mark. Steg kursen herefter, ville låntager få gevinsten, mens kassen ville tage det tab, der ville opstå, hvis markens kurs faldt yderligere. Markbeløb erhvervet efter den 1. oktober 1918 ville kun i ganske særlige tilfælde komme i betragtning som sikkerhed. Afregningskassens virksomhed skulle senest være afsluttet den 31. marts 1921. Derudover havde Finansmini- 
steriet overtalt de fem hovedbanker i København ${ }^{36}$ til at stille kapital til rådighed for kassen, mod at staten stillede sikkerhed mod tab.

De tre forslag indeholdt stort set alt det, nordslesvigerne ikke havde ønsket. For det første en omregning til dagskurs ved alle betalinger. For det andet en hjælp på 25 millioner kroner, langt under det niveau man regnede med i Nordslesvig. For det tredje en afregningskasse, der var fuldstændig afhængig af de københavnske storbanker, og som skulle yde lån $\mathrm{i}$ stedet for almen støtte. Kursreguleringsprincippet var borte, og i stedet skulle 25 millioner kroner fordeles som en direkte økonomisk hjælp efter et erstatningsprincip. Finansminister Brandes vidste, at forslagene stod til forhandling. Det fremgår af hans udtalelse om, at de 25 millioner kroner til udligningskassen muligvis ikke var tilstrækkeligt. Der kan derfor meget vel være et element af taktik i forslagenes begrænsninger. Her var præcis den dæmpelse af nordslesvigernes forventninger, som Kriegerudvalget havde efterlyst på mødet med finansministeren den 26. marts, og som L.V. Birck havde efterspurgt den 17. juni. I betragtning af regeringens stilling $i$ grænsespørgsmålet er det dog bemærkelsesværdigt, hvor meget der i lovforslagene gik direkte imod de onsker, der var kommet fra Nordslesvig. Ved at give Nordslesvig løfter om en større økonomisk støtte kunne regeringen have kompenseret for sin modstand mod at indlemme Flensborg i Danmark. I stedet modsatte regeringen sig ethvert nordslesvigsk ønske til valutareguleringen, og udsatte derved sig selv for endnu mere mistro i grænsespørgsmålet. Det kan undre, at de turde.

\section{Lovforslagenes første behandling}

Onsdag den 6. august 1919 kom Finansministeriets tre lovforslag angående valutareguleringen til første behandling i rigsdagsudvalget. Behandlingen var mest en udveksling af synspunkter, da forslagene skulle gennem endnu et udvalgsarbejde, før de endelig kunne vedtages. En mindre diskussion opstod dog, på foranledning af et spørgsmål fra Niels Neergaard til finansministeren. Neergaard ønskede at vide, om finansministeren kendte til, hvorledes lignende opgaver løstes andre steder i Europa, hvor samme situation forelå. Finansministeren havde kun oplysninger om situationen i Elsass-Lothringen, der var annekteret af Frankrig. Her kunne befolkningen få deres tyske mark omvekslet til parikurs, 1 mark for 1,25 franc. Den franske rege- 


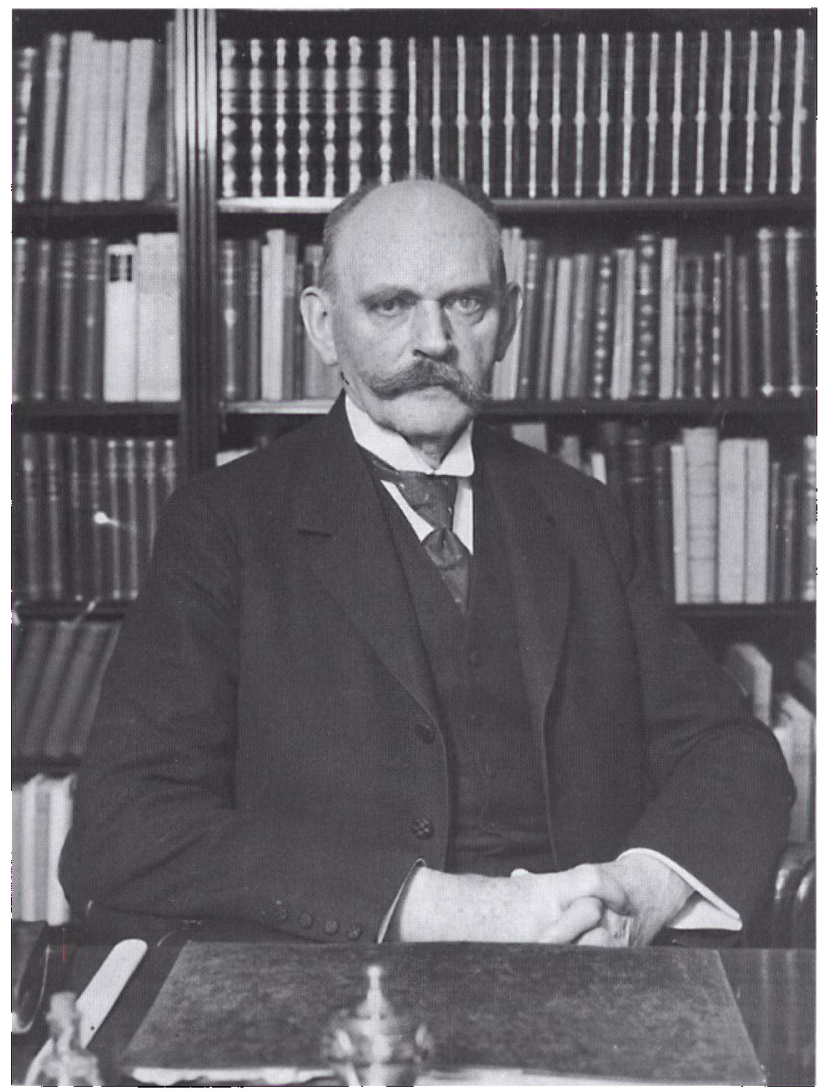

Niels Neergaard

(1854-1936).

Statsminister

1920-1924. Niels

Neergaard tog ak-

tivt del $i$ forhand-

lingerne om kronemontens indforelse $i$ Nordslesvig, som formand for det underudvalg, Rigsdagspartiernes sonderjyske Udvalg havde nedsat til formålet. Neergaard fuldforte som statsminister genforeningen. Foto: Det kongelige Bibliotek.

ring skulle siden have fortrudt dette tilsagn, da ordningen ville koste den franske stat omkring 5 milliarder franc. Finansministeren kunne yderligere oplyse, at da Glückstadt havde fortalt franskmændene om den påtænkte danske ordning, havde de ønsket, at de havde fulgt samme regler. Ordningen i Elsass-Lothringen havde medført, at der blev spekuleret kraftigt i valutareguleringen. Det måtte for hver en pris undgås i Nordslesvig, mente finansministeren.

H.P. Hanssen var også til stede ved behandlingen. Han betonede de individuelle undersøgelsers berettigelse ved at henvise til de meget forskellige okonomiske forhold, der eksisterede i Nordslesvig. For det første var der allerede strømmet en stor mængde tysk kapital, omkring 100 millioner mark, til. Denne kapital måtte udelukkes fra valutareguleringen. For det andet var de interne forhold meget broge- 
de. H.P. Hanssen gav et eksempel herpå. En ung mand havde i 1914 købt en gård for 60.000 mark. Han havde udbetalt de 6000 mark og havde en gæld tilbage på 54.000 mark, svarende til 48.000 kroner. I 1919 havde han optaget et kronelån i Danmark på 18.000 kroner og med disse udbetalt den resterende gæld på 54.000 mark. På grund af valutakursen havde han således reduceret sin gæld med 30.000 kroner, og samtidig var gården steget $\mathrm{i}$ værdi. Sælgeren derimod havde tabt 30.000 kroner på markkursens fald. En beskatning af sådanne valutafortjenester burde ifølge H.P. Hanssen overvejes, og under alle omstændigheder burde den unge mand ikke få hjælp af den danske stat. For at undgå dette var individuelle undersøgelser af de enkelte tilfælde nødvendig. H.P. Hanssen mente desuden, at 25 millioner kroner i udligningskassen var for lidt. Det var muligvis ikke det endelige beløb, men det ville være klogere at sætte beløbet højere for at vise viljen til at hjælpe den nordslesvigske befolkning fra dansk side. H.P. Hanssen frygtede, at regeringen og hans egen stilling i Nordslesvig skulle blive yderligere svækket, hvis regeringen ikke viste vilje til at hjælpe Nordslesvig økonomisk.

\section{Nordslesvigske deputationer og ændringsforslag}

Onsdag den 13. august 1919 mødte en deputation fra Vælgerforeningens økonomiske udvalg og repræsentanter for den nordslesvigske handelsstand til møde i rigsdagsudvalget. Deputationen gav til kende, at nordslesvigerne generelt var særdeles utilfredse med den foreslåede valutaregulerings omfang. Men samtidig var nordslesvigerne også dybt splittet i valutaspørgsmålet. Af samme årsag blev der ikke afleveret et, men to ændringsforslag til Finansministeriets forslag, med to forskellige grupper bag. Christian Hübbe, direktøren for Haderslev Bank, var talsmand for den første gruppe og indledte nordslesvigernes udtalelser. Hübbe stod for den linie, der også var udtrykt i det økonomiske udvalgs betænkning. Essensen af denne holdning findes i Hübbes indledende ord:

Som den rode Traad gennem vore Ønsker og Forhaabninger gaar dette, at vi, naar vi efter Genforeningen blev en Del af det danske Folk, ogsaa $i$ vore økonomiske Forhold maatte blive javnstillet med det samlede danske Folk. $O g$ for at det kan ske, vil det efter min Mening være nødvendigt, at Marken, enten Vardierne nu bestaar $i$ Kontanter eller $i$ Sparekasse- eller Banktilgodehavender, omregnes efter en forbedret Kurs, helst Pari. ${ }^{37}$ 
Ændringsforslagene fra Hübbes gruppe lagde derfor mest vægt på afregningskassen. ${ }^{38}$ Omregningen ved afregningskassen måtte ikke være under 45 kroner for 100 mark. Kun det deponerede markbeløb hæftede for det optagne kronelån, og ved en stigning af markkursen måtte lånet forlanges tilsvarende forhøjet. Kassens virksomhed skulle tidligst afsluttes i 1925. Desuden betragtede gruppen ikke valutaspørgsmålet som endeligt ordnet ved de to lovforslag om afregningsog udligningskassen, men fastholdt synspunkterne fra det okonomiske udvalgs betænkning. ${ }^{39}$

P. A. Callø var talsmand for den anden gruppe i det økonomiske udvalg. Efter Calløs mening burde hverken landbrugerne, købmandsstanden eller håndværket modtage hjælp fra den danske stat. Der var ikke længere noget forhold at udligne mellem kreditorer og debitorer, da der efterhånden kun fandtes kronedebitorer i området. Callø mente derfor, ... at man ganske praktisk maa søge forst at udskille, hvad der kan udskilles, og derefter overveje, hvad der kan gøres ved det, der bliver tilbage, idet man paa Forhaand maa opgive at opnaa ideel Retfxrdighed og kun søge at bode paa Ulykkerne, saa vidt det er muligt. ${ }^{40}$ Endringsforslagene fra Calløs gruppe lagde derfor mest vægt på bestemmelserne vedrørende udligningskassen. ${ }^{41}$ De foreslog, at de 25 millioner kroner blev forhøjet til 75 millioner, hvoraf de 10 millioner kunne anvendes af lånekassen. Lånekassen skulle så give driftslån med en moderat rente til handlende, næringsdrivende og landmænd, der som en følge af krigen eller markens kursfald ikke rådede over tilstrækkelig driftskapital til grundlæggelse eller genrejsning af økonomisk virksomhed.

P.A. Callø fremhævede efter genforeningen sit indlæg om begrænsningen af den økonomiske hjælp på mødet den 13. august som afgørende for den endelige udformning af valutareguleringen. ${ }^{42}$ Calløs indlæg svarede da også til det erstatningsprincip, der blev valutaordningens hjørnesten. Selvom Callø her overfortolkede sin egen betydning i valutaspørgsmålets afgørelse, var Callø den nordslesviger, der udover H.P. Hanssen fik størst indflydelse på valutaordningen. Fordi Callø forholdvis tidligt i forløbet indså, at det drejede sig om at forhøje erstatningsbeløbene og ikke omvekslingskursen, opnåede han denne indflydelse. At Callø så klart tog et ansvar for valutaordningen betød også, at han i løbet af 1920'erne og 30'erne måtte finde sig i megen kritik fra folk i Nordslesvig, der følte sig svigtet af valutaordningen.

I efteråret 1919 tog kronelånene og gældsafviklingen til. Callø fik 


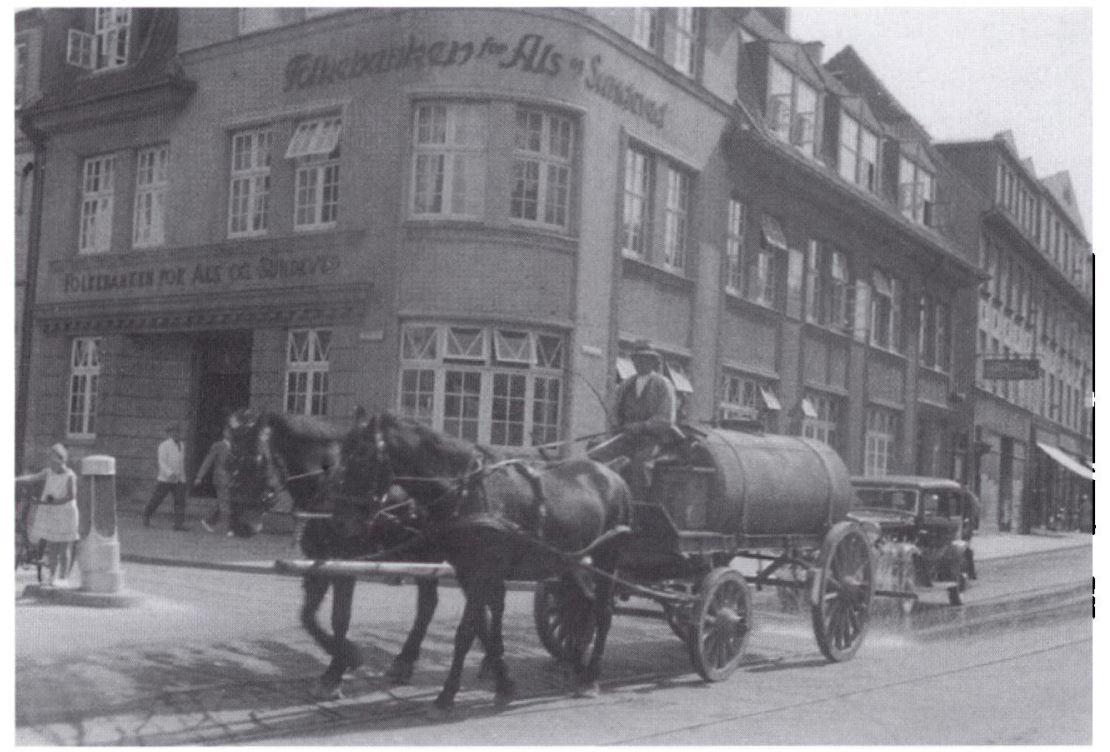

Folkebanken for Als og Sundeveds bygning i Sonderborg omkring 1930-35. Folkebanken blev stiftet $i$ 1909. Fusionerede med Graasten Bank, Nordslesvigsk Folkebank og Tønder Landmandsbank i 1970. Foto: Lokalhistorisk Arkiv for Dybbøl, Ulkebøl og Sonderborg.

derfor efterhånden ret $\mathrm{i}$, at der ikke længere kunne tages udgangspunkt $i$ forholdet mellem kreditorer og debitorer. Samtidig satte et dramatisk fald i markkursen ind i efteråret 1919, jævnfør tabel 1. Jo mere markkursen faldt, jo dyrere ville en kursregulering til fredskurs blive for den danske stat. Det var en væsentlig årsag til, at chancen for en omveksling til fredskurs blev mindre og mindre.

\section{Afgørende forhandlinger}

Foreløbig gik valutaspørgsmålet til udvalgsbehandling i et underudvalg i rigsdagsudvalget, bestående af to medlemmer for hvert parti. ${ }^{43}$ Sidst $\mathrm{i}$ august havde partigrupperne ændringsforslag klar, hvoraf den radikale gruppe stod på ministeriets forslag. Partiernes ændringsforslag og det sønderjydske ministeriums kommentarer til forslagene tegner et billede af grupperingerne i valutasporgsmålet. Der syntes at være opstået en alliance bestående af Callø og hans gruppe i Vælgerforeningens økonomiske udvalg, Venstregruppen i rigsdags- 
udvalgets underudvalg og det midlertidige sønderjydske ministerium, der samlet arbejdede for en forhøjelse af erstatningsbeløbet $i$ udligningskassen. Alliancens overvejelser lå desuden tæe på overvejelser fra flere okonomisk sagkyndige som L.V. Birck og Emil Glückstadt. Den anden nordslesvigske gruppe, med Hübbes krav om pariomveksling, havde fået tilslutning fra den konservative gruppe, men den var hverken stærk nok eller realistisk i sit bud på valutaspørgsmålets løsning. Socialdemokratiet syntes at stå på regeringens side, men meldte ikke for alvor ud om sin holdning.

Den 4. september 1919 blev der afholdt et møde på »Folkehjem « i Aabenraa med deltagelse af Fælleslandboforeningens bestyrelse, Sønderjydsk Arbejderforenings bestyrelse, repræsentanter for kredsudvalgene i Nordslesvig, samt minister H.P. Hanssen. H.P. Hanssen gjorde her rede for valutaspørgsmålets daværende stilling. Han kunne berette, at spørgsmålet lå til behandling i rigsdagsudvalget. Ifølge H.P. Hanssen kunne der ikke findes flertal for en omregning til pari i rigsdagsudvalget. I stedet kunne der findes flertal for en ordning i overensstemmelse med regeringens første udkast til valutaspørgsmålets løsning. Det var med andre ord i en forbedring af dette forslag, kræfterne skulle bruges, hvilket var et nøgternt og fornuftigt budskab set i historiens bakspejl.

H.P. Hanssens synspunkter fandt ikke megen forståelse. Særlig de sønderjyske handelsforeninger stod stejlt på kravet om en omveksling til pari. De næringsdrivende ville desuden ikke udsættes for at få undersøgt deres økonomi af en tilfældig kommission. For at handelsstanden kunne få deres varelagre fyldt før genforeningen, krævede handelsforeningerne også toldfri indførsel af varer fra Danmark, samt at pastvangen mellem Danmark og Nordslesvig blev ophævet. Ellers kunne man ikke modstå konkurrencen, der ville komme fra nord. ${ }^{44}$

I månederne oktober og november 1919 fremlagde henholdsvis det senderjyske ministerium, Niels Neergaard og Socialdemokratiet forslag til valutareguleringen. Fælles for disse forslag var, at erstatningsprincippet var grundstenen. Med både Venstre, Socialdemokratiet og det sønderjyske ministerium på erstatningsprincippets grund faldt kursreguleringsprincippet reelt set bort. Det stod nu klart, at valutaordningen ville bestå af erstatninger for indtægts- og formuetab under krigen.

Den 3. december 1919 fremlagde Finansministeriet et nyt forslag. 
Forslaget afspejlede de forhandlinger, der var foregået over det seneste halve år, siden ministeriets første forslag forelå. Mange elementer af de af det sønderjydske ministerium og særligt Venstre og Socialdemokratiet fremlagte forslag lå i Finansministeriets forslag. Men derudover afspejlede forslaget også Finansministeriets faste overbevisning om, at staten så vidt muligt skulle begrænse sin indblandning $\mathrm{i}$ de økonomiske forhold i Nordslesvig efter genforeningen. Forslaget var nu skåret ned til én samlet udlignings- og lånekasse, med 300 kroner per indbygger til rådighed. Kassens virksomhed skulle ophøre den 31. marts 1921. På den måde var den statslige indsats beskåret til et minimum. Den radikale regering havde under krigen indført en betydelig statslig regulering, der blev voldsomt angrebet af erhvervslivet og især Det Konservative Folkeparti. Det besynderlige er, at $i$ valutaspørgsmålet var det den radikale regering der stod som hovedeksponent for økonomisk selvregulering, mens Det Konservative Folkeparti godt kunne acceptere en større statslig indsats.

Den 17. december 1919, mødte endnu en nordslesvigsk deputation op i rigsdagspartiernes sønderjydske udvalg for at tale om valutaspørgsmålet. Med sig havde deputationen en petition underskrevet af omtrent 45.000 nordslesvigere. Petitionens budskab var, at en valutaordning af den art, som der nu forelå, ville ruinere store dele af den nordslesvigske befolkning. I forlængelse deraf lød forslaget: Den retfærdigste Ordning vil være at den løse, legitimt erhvervede Markkapital omregnes til Pari, under Udelukkelse af Krigsvinding og fremmed Kapital. ${ }^{45}$ Parikurskravet var dermed blevet begrænset til den løse kapital, og skulle ikke længere omfatte både gæld og tilgodehavender. Den noget sene indrømmelse var imidlertid ikke anvendelig, set i lyset af valutaspørgsmålets forhandlingsstadie. Christian Hübbe var hovedkraften bag petitionen, og han oprettede $i$ forbindelse med denne en valutakommission i Haderslev, bestående af en række af petitionens underskrivere. Kommissionen skulle være talsmand for de 45.000 underskrivere og forsøge at påvirke forhandlingerne i København. Vælgerforeningens økonomiske udvalg var i mellemtiden blevet opløst, og nordslesvigerne manglede en interesseorganisation. Valutaspørgsmålet var imidlertid i sin afgørende fase, og erstatningsprincippet var blevet hjørnestenen $i$ forhandlingerne. Den nyoprettede valutakommission fik derfor aldrig nogen egentlig indflydelse på valutaordningen. Nordslesvigerne var kørt ud på et sidespor, og forstod ikke at ændre kurs. 


\section{Sønderjysk kroneudvalg}

Valutaspørgsmålet var nu nået så langt, at de praktiske forberedelser af kronemøntens indførelse kunne påbegyndes. Dertil blev »Udvalget for Afhjælpning af de med Kronemøntens indførelse i Sønderjylland forbundne Vanskeligheder« nedsat den 18. december 1919. Udvalget havde følgende opgaver:

1) At foretage en nøje Undersøgelse af, hvor mange og hvor store Kronelaan Sønderjyderne har optaget her i Kongeriget og under hvilke Former og paa hvilke Vilkaar, de er optagne,

2) at bistaa Sønderjyderne med Opretholdelsen af en midlertidig Kronekredit paa rimelige Vilkaar og

3) i det hele at overveje og eventuelt stille Forslag om hvilke Foranstaltninger, der bør og kan foretages for at gøre Overgangen fra Mark til Krone saa let som muligt for det økonomiske Liv i Sønderjylland. ${ }^{46}$

Formand for udvalget blev statsgældsdirektør P.O.A. Andersen, der også havde deltaget $\mathrm{i}$ det første møde om valutaspørgsmålet den 22. januar 1919. Martin Hammerich blev det sønderjydske ministeriums repræsentant i udvalget. Orla Buhl, 2. direktør for den nye kreditforening i Sønderjylland, var det sidste rigsdanske medlem. De nordslesvigske medlemmer blev gårdejer P.J. Refshauge, dr. Karberg fra Sønderborg, købmand Holger Fink fra Aabenraa, samt bankdirektør Rossen fra Tønder. En enkelt flensborger, bankdirektør Jespersen, startede i udvalget, men trak sig tilbage og erstattedes af bankdirektør og borgmester i Kolding, Oluf Bech. Axel Hulegaard blev udvalgets sekretær. Disse medlemmer fik en stor betydning i valutaspørgsmålets sidste faser.

\section{Kroneudvalgets arbejde og lånekassen}

Når kroneudvalget fik en betydelig rolle i valutaspørgsmålets sidste faser skyldtes det ikke mindst, at udvalget straks tog fat om helt konkrete og praktiske problemer ved kronemøntens indførelse i Nordslesvig. Det var særligt fire opgaver, udvalget tog fat på i december 1919. For det første indsamlingen af det statistiske materiale vedrørende kronelånene. Udvalget havde allerede i februar 1920 skaffet sig 
overblik over kronelånenes antal og størrelse. Omtrent 50 millioner kroner havde nordslesvigerne lånt $i$ Danmark på det tidspunkt. For det andet satte udvalget sig i kontakt med Nationalbanken for at sikre, at denne ville holde tilstrækkelige mængder af sedler og skillemønt klar til udspredning i Nordslesvig. Desuden bad udvalget banken om at skaffe udvej for, at nordslesvigerne kunne opnå fornødne kronelån på billige vilkår så hurtigt som muligt. Kroneudvalget gik i forhandlinger med Nationalbanken, der som de fleste andre rigsdanske instanser var noget forbeholden i sin vilje til at støtte nordslesvigerne økonomisk. Det fremgår af et brev, nationalbankdirektør Ussing sendte til kroneudvalgets formand P.O.A. Andersen den 27. januar 1920. I brevet beskriver Ussing fordelene ved at give en del af erstatningerne til Nordslesvig som statsobligationer. Statens finanser var ifølge Ussing i en tilstand, der betød, at staten måtte holde mest muligt på de kontante beholdninger. Det ville heller ikke gavne pengeog seddelvæsenet, hvis store mængder af kontanter blev ledt ud i Nordslesvig.

Kroneudvalget indgik også i forhandlinger med regeringen og Finansministeriet om at stille midler til rådighed til forskellige forhold i forbindelse med kronemøntens indførelse. Udvalget var i den forbindelse en stor hjælp for den nyoprettede Sønderjyllands Kreditforening. Regeringen blev bedt om at stille 10 millioner kroner til rådighed for støtteopkøb af den første obligationsrække, samt 50.000 kroner til kreditforeningens startudgifter. At kroneudvalget gennem Orla Buhl havde et interessesammenfald med kreditforeningen synes ikke at være bemærket. Kroneudvalget bad også regeringen om at stille midlertidige lån på 3 millioner kroner til rådighed for hver af de fire største banker i Nordslesvig, og mindre lån til sparekasserne. Regeringen accepterede alle forespørgsler.

Kroneudvalget lagde for det fjerde store kræfter i oprettelsen af lånekassen og overtog med tiden helt lånekassen som sit område. På et møde i kroneudvalget den 23. januar 1920 vedtog udvalget et forslag til lov om oprettelsen af lånekassen og tilstillede det sønderjydske ministerium forslaget. Lånekassens opgave skulle være at træde til i de tilfælde, hvor sikkerhed for lån ikke kunne ydes, men hvor forholdene i øvrigt talte for at støtte den pågældende. Lånene kunne ydes til næringsdrivende, handlende og landbrugere. Kassen skulle have et beløb på 15 millioner kroner stillet til rådighed og forvaltes af kroneudvalget selv. Det var efter kroneudvalgets mening særligt 
mellem- og middelstanden, der skulle nyde godt af kassens midler, og ikke de fattigste, som skulle hjælpes af udligningskassen. Kroneudvalget ville således give lånekassen et noget større spillerum og langt flere midler, end Finansministeriet havde lagt op til. Udvalget ønskede blandt andet en lånegrænse på 10.000 kroner. Kroneudvalget var klar over, at der skulle bruges forholdsvis store midler til at sætte det nordslesvigske erhvervsliv i gang igen. Alligevel ville heller ikke dette udvalg ubetinget forhøje den økonomiske hjælp til Nordslesvig. I kroneudvalgets beretning til Rigsdagspartiernes sønderjydske Udvalg, skrevet i marts 1920, findes et klart udtryk for udvalgets syn på genoprettelsen af den nordslesvigske økonomi. Her hedder det: I det hele har Udvalget anset det for det heldigste for det økonomiske Liv $i$ Sønderjylland, at de til dettes Betjening og Fremme existerende og egnede sædvanelige Organer $i$ storst mulig Omfang kommer til at opfylde deres Funktioner, således at Næringslivet og Finanslivet hurtigst muligt bringes under de Former, der for Fremtiden tor anses at blive onskelige som normale og sædvanelige. ${ }^{47}$

Sagt på en anden måde, skulle den danske stat så vidt muligt overlade det økonomiske liv i Sønderjylland til sig selv og ikke gribe regulerende ind på alle områder. Kun hvor det var allermest nødvendigt, skulle der ydes særlig økonomisk hjælp til sønderjyderne. Kroneudvalget overtog på dem måde den danske regerings, centraladministrations og finansverdens hidtidige holdning til det nordslesvigske valutaspørgsmål om mindst mulig statslig indblanden og størst mulig selvregulering.

\section{Den internationale kommission for Slesvig}

Mens valutaspørgsmålet $\mathrm{i}$ efteråret og vinteren 1919-20 lå i afgørende forhandlinger og var ved at blive bragt til en løsning, havde også grænsespørgsmålet været i en afgørende fase. Nordslesvigsk Vælgerforening havde $i$ august 1919 delt sig i to fløje, bestående af et flertal, der delte H.P. Hanssens synspunkter angående en grænse nord om Flensborg, og et mindretal, der onskede Flensborg og helst hele 2. zone tilsluttet Danmark, med eller uden dansk flertal. Når grænsestriden blev så voldsom, skyldtes det ikke mindst, at en afgørelse syntes at trække ud i det uendelige. Uvisheden skabte kaotiske tilstande i området, som blev værre, jo længere afgørelsen trak ud. Den økonomiske og ernæringsmæssige situation i både Nord- og 
Sydslesvig forværredes fra dag til dag, fordi forsyninger fra Tyskland udeblev, og fordi markkursens fald gjorde forsyninger fra Danmark dyrere og smughandel tillokkende. Det var svære administrative vilkår C.I.S skulle overtage.

Den 10. januar 1920 blev Versaillestraktaten endelig ratificeret i Paris. Ratifikationen betød, at den internationale kommission for Slesvig kunne påbegynde sit egentlige arbejde. Som en af de første handlinger blev afstemningen i 1. zone sat til den 10. februar 1920. Den 26. januar 1920 ankom den internationale kommissions medlemmer til Flensborg, hvor »Hotel Flensburger Hof « blev indrettet som kommissionens hovedkvarter. ${ }^{48}$ Slesvig var fra da af et internationalt område.

\section{Valutaspørgsmålets løsning}

Afstemningen i 1. zone nærmede sig. Agitationen for tyske og danske stemmer tog til i styrke og skarphed. Fra tysk side vedblev den danske rigsdags manglende udmelding om valutaordningen at være et angrebspunkt. I rigsdagsudvalget var man derfor klar over, at en afklaring før afstemningen i 1. zone den 10. februar 1920 var nødvendig. Rigsdagsudvalgets underudvalg for valutaspørgsmålet var presset til opnå enighed om en ordning. Tirsdag den 3 . februar 1920 måtte underudvalgets formand, Niels Neergaard, derfor fremlægge de forslag, som underudvalget havde kunnet enes om. I fremlæggelsen lagde Neergaard ikke skjul på, at enigheden kun var blevet opnået under det pres, som situationen udgjorde. Sønderjyderne kunne ikke vente længere på en udmelding, og ingen af de danske partier kunne forsvare at fremprovokere et valg på spørgsmålet. ${ }^{49}$ Det valg var der ellers mange inden for den borgerlige fløj, der gerne snart så udskrevet.

Afregningskassen var bortfaldet. Forslaget om kronemøntens indførelse var der ikke sket ændringer ved. Forslaget var, som Finansministeriet havde foreslået det i juli 1919. Det gjorde dansk møntlovgivning gældende mand og mand imellem samt ved offentlige kasser, og omregningskursen ville være den gældende dagskurs, hvis ikke finansministeren mente andet. Det var i udligningskassens regelsæt, at nye bestemmelser forelå. Udvalget havde fastsat, at kassen fik stillet 350 kroner per indbygger til rådighed. Efter den tyske folketælling fra 1910 drejede det sig om 167.000 mennesker i 1. zone og om 109.000 mennesker i 2. zone. I alt 276.000 mennesker og et samlet beløb på 
96.600.000 kroner. Chancen for et dansk flertal i 2. zone blev således stadig regnet for en mulighed. Skulle afstemningen i 2 . zone tages alvorlig, var de danske politikere ganske enkelt nødt til at træffe en sådan bestemmelse. Udover de godt 97 millioner kroner skulle 10 millioner stilles til rådighed for den lånekasse, som kroneudvalget stadig arbejdede med. 106.600 .000 kroner skulle således i alt rejses til udlignings- og lånekassen.

Partierne var blevet enige om en erstatning for tabte værdier til personer, der den 1. januar 1914 havde en formue der udgjorde indtil 5.000 mark, ved en kurs på 8 kroner for 9 mark. Personer med formuer på indtil 15.000 mark i 1914 kunne få de første 5.000 tabte mark erstattet som ovenfor, de næste 5.000 til kurs 45 og de næste 5.000 efter en kurs fastsat af forvaltningsrådet, dog ikke over 45 . Herefter kunne tab erstattes med en kurs faldende med 5 for hver 10.000 mark. Erstatningerne kunne ikke udgøre mere end 25.000 kroner per modtager. Ikke-familieforsørgere måtte nøjes med $2 / 3$ af erstatningssummen. Rente og pensionstilskuddenes udformning var man endnu ikke blevet helt enige om, men grundlinierne $\mathrm{i}$ reglerne blev fremsat. Uenigheden gjaldt spørgsmålet om kapitalrenter. Personer, der var henvist til at leve af renten af en kapital, skulle også have tilskud. Spørgsmålet var, om der skulle lægges en begrænsning på den kapitalstorrelse, hvoraf vedkommende fik sine renter? Regeringen mente, at begrænsningen burde være på 50.000 mark, mens Venstre og Konservative var imod en sådan grænse. I alle tilfælde skulle tilskuddene betales tilbage uden renter ved pågældende modtagers død.

Det endelige forslag var et kompromis mellem de forslag, som vi tidligere har set fremsat af de forskellige parter. Finansministeriet havde med forslaget fra den 30. juli 1919 sat dagsordenen for valutaspørgsmålet, men Venstre og det sønderjydske ministerium havde formået at hæve den økonomiske indsats fra den danske stats side væsentligt. Nu taltes der om 97 millioner kroner, hvor Finansministeriets første bud lå på 25 millioner kroner. Finansministerens taktik var lykkedes. Netop fordi de første udkast var så beskedne i omfang, kom prisen for valutaordningen aldrig op i de lejer, som foreslået fra Nordslesvig. Hübbe havde blandt andet foreslået 180 millioner kroner til den nordslesvigske valutaordning alene. Neergaard omtalte i sin fremlæggelse det så længe og stædigt fremsatte forslag fra Christian Hübbe og dennes forbundsfæller om en omveksling til fredskurs af 
hele markformuen. Forslaget var ifølge Neergaard blevet diskuteret længe og intenst $\mathrm{i}$ underudvalget. Når det i sidste ende måtte afvises, var det mest af alt på grund af markkursens fald. Den 2. februar var markkursen nede på 7,10 kroner for 100 mark. En omveksling til fredskurs ville med en sådan kurs blive meget kostbar for den danske stat. $^{50}$

Neergaard omtalte også finansieringen af genforeningens omkostninger. Folketinget havde den 3. september 1919 vedtaget, at den danske stat optog et genforeningslån på 145 millioner kroner. ${ }^{51} \mathrm{Da}$ genforeningen også ville koste omkring 100 millioner kroner i erstatningssummer til Tyskland for overtagelsen af statsejendomme og jernbaner, samt den del af den tyske statsgæld Danmark overtog med Slesvig, ville genforeningslånet ikke række. ${ }^{52}$ Det var derfor besluttet, at salgsummen for de vestindiske øer også måtte anvendes på genforeningen. Denne salgssum lå endnu ikke fast, men ville ifølge Neergaard skønsmæssigt udgøre mindst 100 millioner kroner. I alt var der næsten 250 millioner kroner til rådighed. De 200 millioner var brugt med udlignings- og lånekassen og erstatningssummen til Tyskland. Tilbage var godt 50 millioner, som ifølge Neergaard måtte henlægges til senere brug i Sønderjylland, hvor infrastrukturen og sundhedsvæsenet ville kræve store investeringer fra den danske stats side. Rigsdagspartiernes sønderjydske Udvalg tilsluttede sig hovedpunkterne i udvalgets forslag, og H.P. Hanssen kunne dagen efter rejse til Nordslesvig og fremlægge den valutaordning, der nu var blevet fremlagt, og som nordslesvigerne kunne regne for endelig.

\section{Afstemningerne og valutaordningens vedtagelse}

Den 10. februar 1920 blev afstemningen i 1. zone afholdt. Det samlede resultat blev $74,9 \%$ danske stemmer og $25,1 \%$ tyske stemmer. Anderledes gik det ved afstemningen i 2. zone den 14. marts 1920. Resultatet var her sammenlagt $19,8 \%$ danske stemmer og $80,2 \%$ tyske stemmer. Resultatet var en enorm skuffelse for mange danskere. Flensborg havde opnået $24,8 \%$ danske stemmer, hvilket faktisk var et godt resultat set $\mathrm{i}$ lyset af de $4 \%$ danske stemmer, der var opnået $\mathrm{i}$ byen ved rigsdagsvalget i 1912, men ville højst sandsynlig ikke blive dansk område. ${ }^{53}$

Da rigsdagsudvalget den 3 . februar havde vedtaget hovedlinierne i det, der skulle blive den endelige valutaordning, var man nu også i 
Nordslesvig klar over, hvorledes denne ordning med størst sandsynlighed ville komme til at se ud. Alligevel overstrålede uvishederne de retningslinier, der var blevet forelagt fra rigsdagsudvalget. Der forelå stadig ingen egentlig lov, og fra flere sider, særlig i håndværket og industrien, var der stadig tro på, at en forbedret ordning kunne opnås. ${ }^{54}$ Ikke mindst var tidspunktet for kronemøntens indførelse stadig ukendt. Afstemningen den 10. februar gjorde det klart, at Nordslesvig ville blive dansk, men ikke hvornår. Afstemningsresultatet betød, at myndighederne i Tyskland nu helt ignorerede bestående problemer i Nordslesvig. Det var derfor såre nødvendigt, at den sidste tvivl om valutaspørgsmålet blev begravet.

Den 26. marts 1920 vedtog rigsdagsudvalget derfor de tre lovforslag om det nordslesvigske valutaspørgsmåls ordning, så rigsdagen blot skulle sætte dem i værk, når suverænitetsforholdene muliggjorde dansk lovgivning i Nordslesvig. Kun ganske få justeringer i forhold til forslagene fra den 3. februar var at finde $i$ de vedtagne love, hvilket dog mest af alt skyldtes tidspresset. Af den diskussion, der opstod ved vedtagelsen, fremgår det, at flere partier ønskede ændringer, men at ingen turde genåbne forhandlingerne, der nu havde stået på siden juli 1919. Uenigheden om en begrænsning af kapitalstørrelsen for rentetilskud var endt med en fjernelse af begrænsningen. Desuden var det blevet tilføjet, at formuer på indtil 1000 mark, der bevisligt var opstået i tidsrummet 1. januar 1914 til 1. januar 1919, og siden tabt, i særlige tilfælde kunne erstattes på samme måde som tab under krigen. Ved at bruge datoen 1. januar 1919 mente man at udelukke den største spekulations- og smugleriperiode, der lå efter 1. januar 1919.

Sluttelig var også et lovforslag om lånekassen blevet gjort færdig. Til kassen var der stillet 10 millioner kroner til rådighed. Lånekassen skulle som bekendt yde driftslån til handlende, næringsdrivende og landbrugere, der ikke rådede over eller kunne skaffe tilstrækkelig med midler til at grundlægge eller opretholde en akonomisk virksomhed. Lånesummen måtte ikke overstige 4000 kroner. Lånene forrentedes med $4 \%$ årligt og skulle afdrages over 10 år. I særlige tilfælde kunne rente- og afdragsfrie lån ydes i højst 3 år. ${ }^{55}$

På ét punkt var reglerne for både udlignings- og lånekassen bemærkelsesværdige. Udligningskassens virksomhed skulle ifølge lovforslaget standse den 31. marts 1921 og lånekassens udlånsvirksomhed ved udgangen af finansåret 1921-22. Datoerne afspejler det ønske, 


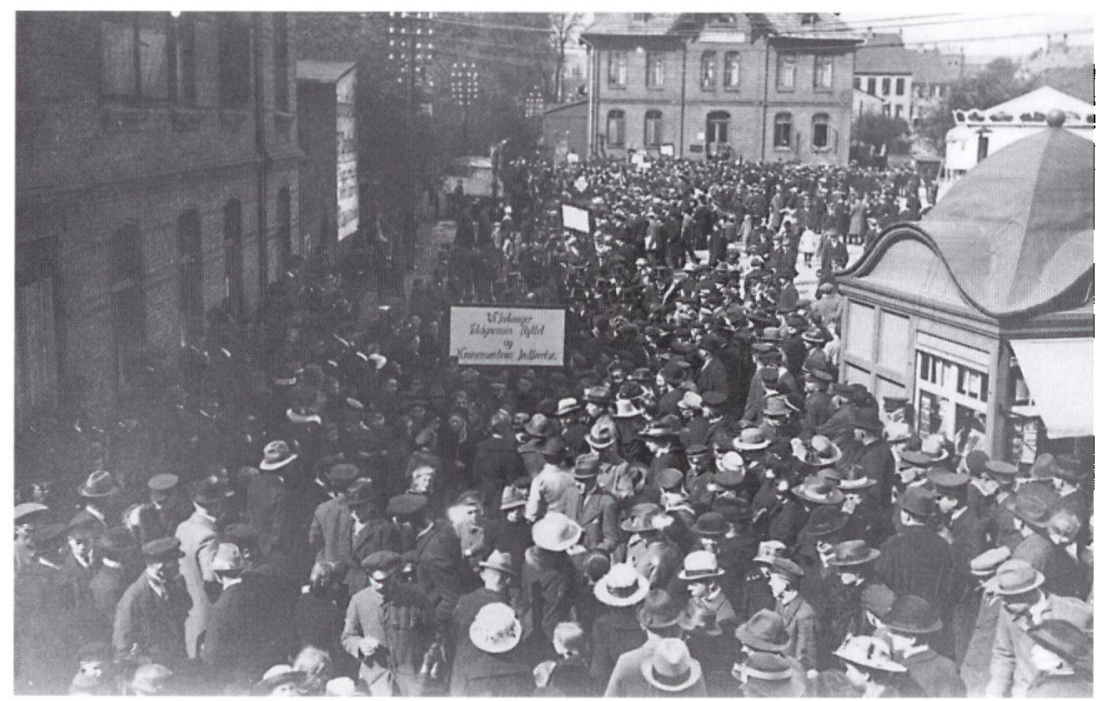

Demonstration på Gravene $i$ Haderslev omkring april-maj 1920 for kronemontens indførelse. Den slags demonstrationer var hverdagskost $i$ Nordslesvig $i$ foråret 1920. Foto: Haderslev Byhistoriske Arkiv.

der længe havde været primært hos de grupper, der havde arbejdet med valutaspørgsmålet $\mathrm{i}$ Danmark. Den økonomiske støtte fra den danske stat skulle være præcist rettet mod de mest trængende og hurtig overstået. Økonomien og erhvervslivet i Nordslesvig skulle hurtigst muligt kunne overlades til sig selv.

Trods Påskekrisen og regeringen Zahles afsættelse den 29. marts 1920 underskrev et flertal $i$ den internationale kommission den 16. april et forslag til en ny dansk-tysk grænse, der fulgte 1 . zones sydgrænse, mens et mindretal foreslog en lidt sydligere grænse. Ambassadørrådet i Paris vedtog den 8. maj flertallets forslag. ${ }^{56}$ Det lå dermed fast, at kun 1. zone skulle genforenes med Danmark. Det var imidlertid ikke afgjort, hvornår kronemønten ville blive indført. Det blev det store spørgsmål i Nordslesvig i foråret 1920.

\section{Hvornår kommer kronemønten?}

Torsdag den 15. april blev der afholdt et møde i Aabenraa mellem bestyrelserne for de sønderjydske handelsforeninger, håndværkerforeningerne, arbejderforeningerne og landboforeningerne, samt H.P. 
Hanssen, Martin Hammerich og Oluf Bech. Mødet handlede udelukkende om kronemøntens indførelse. H.P. Hanssen kunne berette, at afskedigelsen af regeringen Zahle betød, at der måtte regnes med en udskydelse af genforeningen på antagelig tre måneder. Det siddende forretningsministerium under ledelse af M.P. Friis kunne ikke træffe vidtrækkende beslutninger om valutaspørgsmålet, dertil havde det ikke mandat. Kommissionen var ifølge H.P. Hanssen villig til at tillade dansk militær og delvis civil besættelse, men toldgrænsen kunne ikke flyttes. Kun en delvis indførelse af kronemønten kunne lade sig gøre. Valutaloven og lånekasseloven kunne kun indføres under dansk suverænitet og stod således tre måneder ude $\mathrm{i}$ fremtiden. Det var således dystre udsigter, den tidligere minister kunne stille nordslesvigerne i udsigt. De forskellige bestyrelser udtalte sig alle imod en delvis indførelse af kronemønten. Samtidig blev der udtrykt bekymring for plyndringer og generel uro. Arbejderforeningen meldte om generalstrejker, hvis ikke kronemønten straks blev indført. Budskabet fra samtlige tilstedeværende lød: Lad kronemønten og genforeningen komme så snart som muligt, hvis ikke Nordslesvig skal ende i totalt kaos. H.P. Hanssen foreslog de forskellige foreninger at udtrykke deres holdninger $\mathrm{i}$ resolutioner og sende disse til den internationale kommission i Flensborg, hvilket de forskellige bestyrelser da også gjorde.

\section{Toldgrænsen og dansk besættelse af 1. zone}

I afstemningstiden var det den internationale kommission for Slesvig, der stod for administrationen af afstemningsområdet. Tyskland havde imidlertid stadig den formelle suverænitet. Det betød at Danmark ikke kunne lovgive for Nordslesvig, før den endelige grænse var notificeret. Hvis kronemønten skulle indføres før den endelige genforening, var det den internationale kommission der skulle afgøre det. Kommissionen var nødsaget til at omgås suverænitetsforholdene med omhu for at Tyskland kunne anerkende dens virke. Kronemøntens indførelse var afhængig af, at toldgrænsen mellem Danmark og Tyskland blev flyttet fra Kongeåen og til 1. zones sydgrænse. Hvis ikke toldgrænsen flyttedes ville det være umuligt at styre tilførslen af varer til området og dermed priserne. Toldgrænserne er en central del af et lands suverænitet, hvorfor Tyskland ikke var villig til at flytte denne. Efter lange og drøje forhandlinger mellem de danske og tyske 


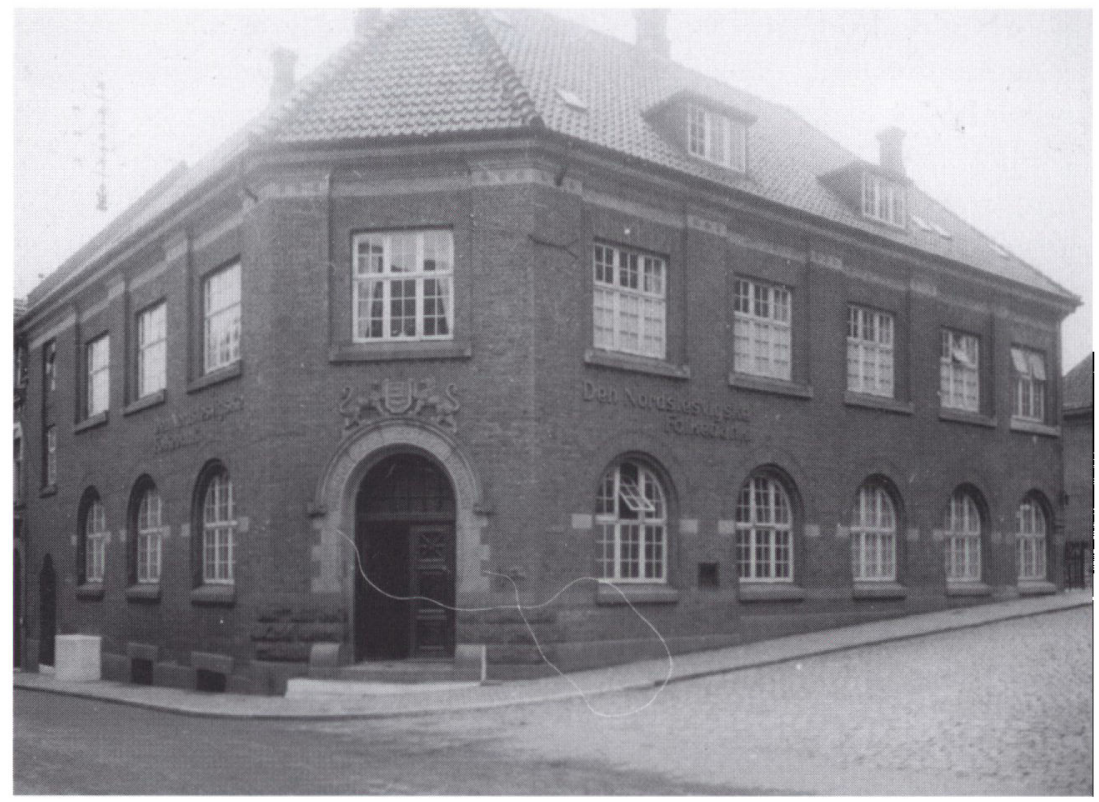

Den Nordslesvigske Folkebank, Aabenraa omkring 1920. Nordslesvigsk Folkebank blev stiftet $i$ 1872. I 1970 tog banken initiativ til Sydbankfusionen med Graasten Bank, Folkebanken for Als og Sundeved og Tønder Landmandsbank. Foto: Institut for sønderjysk Lokalhistorie.

regeringers repræsentanter og den internationale kommission fandt grev Reventlow fra det danske udenrigsministerium en løsning. I stedet for at flytte toldgrænsen kunne grænsen mellem 1. og 2. zone afspærres. Den løsning kunne den internationale kommission tilslutte sig, og vejen var dermed banet for kronemøntens indførelse. Den 29. april underskrev generalsekretæren for kommissionen, BrudenellBruce, og den danske regerings repræsentant, amtmand Lundbye, en aftale om dansk besættelse af 1 . zone og en afspærring af grænsen mellem 1. og 2. zone den 5. maj 1920. Med besættelsen den 5. maj overtog Danmark administrationen af 1 . zone.

Samme dag som den danske besættelse af 1 . zone fandt sted, den 5. maj, tiltrådte den nye Venstreregering med Niels Neergaard som statsminister. Regeringen Neergaard tog med det samme stilling til valutaspørgsmålet. I et telegram fra Brudenell-Bruce, der på dette tidspunkt opholdt sig i Kobenhavn, til kommissionen i Flensborg, dateret den 9. maj, skrev Bruce, at den danske regering gerne så en 
officiel anmodning fra den internationale kommission om at indføre kronemønten i 1 . zone. Den danske regering skulle derefter sende den vedtagne valutaordning til den internationale kommission, som så ville offentliggøre denne som en officiel anordning. Den 12. maj måtte statsminister Neergaard derfor bede rigsdagsudvalget og Finansudvalget om foreløbig at godkende kronemøntens indførsel som en kongelig anordning. Suveræniteten over 1. zone tilhørte stadig Tyskland, så en officiel vedtagelse af rigsdagen kunne der ikke blive tale om. Det særlig problematiske ved det forhold var, at valutaordningen krævede, at den danske stat stillede omtrent 97 millioner kroner til rådighed. Fra socialdemokratisk og radikal side blev der da også udtrykt nogen skepsis over metoden. Men som Neergaard udtrykte det, forekom det ham at være en meget tvingende grund, beslutningen blev taget på. Og sammen med Finansudvalget gav rigsdagspartiernes sønderjydske udvalg da også sin tilslutning, trods den klare omgåelse af grundlovens paragraf 48: Ingen Udgift maa afholdes, som ikke har hjemmel $i$ den af Rigsdagen vedtagne Finanslov eller $i$ en af Rigsdagen vedtaget Tillægsbevillingslov eller midlertidig Bevillingslov. ${ }^{57}$

Rigsdagsudvalget benyttede samtidig lejligheden til at foretage småændringer i valutaordningen. Lånekassen fik, på anbefaling af kroneudvalget, lånegrænsen sat op til 10.000 kroner. Bestyrelsessammensætningen af valutarådet blev ændret, således at det blev pålagt de fire kredsdage at udpege hver to personer, en fra byerhvervene og en fra landbrugserhvervet, til at indtræde $i$ valutarådet. Desuden skulle de seks hovederhvervsorganisationer hver udpege et medlem. Det blev ligeledes vedtaget, at de fire største banker i Nordslesvig hver skulle modtage lån på 3 millioner kroner, samt at fem mindre banker skulle modtage lån på $i$ alt 2,35 millioner kroner. 72 nordslesvigske sparekasser skulle modtage mindre lån på gennemsnitlig 20.000 kroner. Sammenlagt skulle den danske stat udlåne cirka 16 millioner kroner til de nordslesvigske banker og sparekasser. 10 millioner kroner skulle sættes til side til brug for støtteopkøb af Sønderjyllands Kreditforenings første obligationsrække. Til sidst blev der tilføjet et forslag om at give de nordslesvigske arbejdere løntillæg for den sidste uge før kronemøntens indførelse. Det ville dreje sig om omtrent 2 millioner kroner. Forslaget måtte dog først i udvalgsbehandling og kunne ikke vedtages på dagen. Med lånekassens 10 millioner kroner og udligningskassens 63 millioner kroner kom beløbet 
i alt op på omtrent 97 millioner kroner. ${ }^{58}$ Det var omtrent det beløb, der i marts 1920 blev nævnt som udligningskassens rådighedsbeløb, hvis 2. zone også var blevet dansk. At grænsespørgsmålets udfald frigjorde et betragteligt beløb til andre formål blev hverken nævnt eller diskuteret.

\section{Kronemøntens indførelse}

Den 14. maj 1920 blev anordningerne vedrørende valutareguleringen offentliggjort. Det vil sige anordninger om kronemøntens indførelse den 20. maj, om oprettelsen af lånekassen og om valget af medlemmer til valutarådet. Samtidig fulgte en række anordninger med tilknytning til kronemøntens indførsel. Tysk skattelovgivning blev annulleret i 1. zone. Ind- og udførsel af varer fra afstemningsområdet og mellem 1. og 2. zone blev, med undtagelse af indførsel af forsyninger fra Danmark til 1. zone, forbudt. Den 18. maj fulgte en anordning, der forbød pengerepræsentativer, det vil sige nødpenge, i 1. zone, samt en anordning angående indforslen af postfrimærker i kronemønt. ${ }^{59}$

Den sønderjyske valutakommission, der var blevet oprettet af Christian Hübbe, forsøgte en sidste gang at påvirke valutareguleringen ved at henvende sig til statsminister Neergaard. En skrivelse blev udformet den 8. maj, og den 14. maj mødte en mindre deputation statsministeren. Valutakommissionen havde indset, at erstatningsprincippet ikke stod til at ændre. Der var derfor ikke krav om en fredskursomveksling men om højere erstatningssummer, som blev fremført. Det var særligt næringsdrivende, rentierer og pensionister, der ikke kunne være tilfredse med den fremlagte ordning. Valutakommissionen foreslog, at fordelingen ud over de første 5.000 tabte mark blev frigjort for regler, således at valutarådet først kunne undersøge, hvor meget hjælp der var nødvendig. Det blev også nævnt, at gårdejere og større ejendomsbesiddere ikke havde behov for økonomiske tilskud. ${ }^{60}$ At deputationen mødte statsministeren den 14. maj, dagen hvor den internationale kommission offentliggjorde anordningerne vedrørende kronemøntens indførelse, vidner om, at valutakommissionen for sent havde erkendt, hvor kræfterne mest effektivt kunne bruges. Det skulle senere vise sig, at spørgsmålet om rentierernes erstatninger måtte revideres, og at valutakommissionen her havde en god sag. 


\section{Den 20. maj 1920 og generalstrejkerne derefter}

Direktøren for Nationalbankens filial og borgmester i Kolding, Oluf Bech, var blevet udset til at sørge for kronemøntens håndgribelige indførsel i Nordslesvig. De mængder af sedler og skillemønt, der skulle indføres i 1. zone, var blevet opsamlet i Kolding i dagene før den 20. maj. Klokken 7.00 om morgenen den 20. maj kørte en kortege af biler, heriblandt en lastbil, af sted fra Kolding lastet med en stor mængde splinternye danske sedler og mønter. Hvor mange kroner, Oluf Bech bragte med sig på dagen, er usikkert, men i hvert fald de 16 millioner kroner, som i første omgang var tiltænkt de nordslesvigske banker og sparekasser. På grund af den værdifulde last tog et par gendarmer plads i køretøjerne ved grænsen. Fra Kolding gik turen til Haderslev, hvor den gamle Nordslesvigske Kreditforening lagde kontorer til fordelingen af kronemønterne. Pengene blev anbragt på en række dertil opstillede borde, optalt $i$ bunker til hver af de pågældende nordslesvigske banker og sparekasser, der måtte møde op i Haderslev og modtage deres andele. Fordelingen forløb ifølge Oluf Bech glat og var færdig ved frokosttid. ${ }^{61}$ Forventningerne til kronemønten var store. Nu ville der igen komme orden på økonomien, troede man. Det var imidlertid det modsatte, der skete.

Den langt højere værdi, kronen havde i forhold til marken, afspærringen af varetilførslen fra syd og den stadig opretholdte tyske toldkontrol ved Kongeågrænsen, betød, at priserne steg eksplosivt $i$ Nordslesvig umiddelbart efter kronemøntens indførsel. Selvom arbejderne i Nordslesvig modtog løntillæg for ugen før den 20. maj, således at ugelønnen blev 110 kroner for faglærte og 100 kroner for ufaglærte, forblev der en tilstand af utilfredshed og uro inden for arbejderstanden. På grund af prisstigningerne mente de nordslesvigske arbejdere, at højere lønninger i Nordslesvig end i resten af Danmark var nødvendige. De forlangte 2 kroner i timen mod de 1,40-1,60 kroner, der var dansk standard. Fagbevægelsen og de socialdemokratiske partiforeninger besluttede på et fællesmøde i Aabenraa at etablere generalstrejker $\mathrm{i}$ de fire nordslesvigske købstæder fra og med den 3. juni med kravet om 2 kroner i timen som grundlag. Administrator for de sønderjydske landsdele, Viggo Haarløv, gik i forhandlinger med repræsentanter for arbejderbevægelsen som mægler, men kunne ikke ændre arbejdernes beslutning. I Aabenraa, Sønderborg og Tønder blev der strejket fra den 3 . juni til den 15. juni, i Haderslev fra 


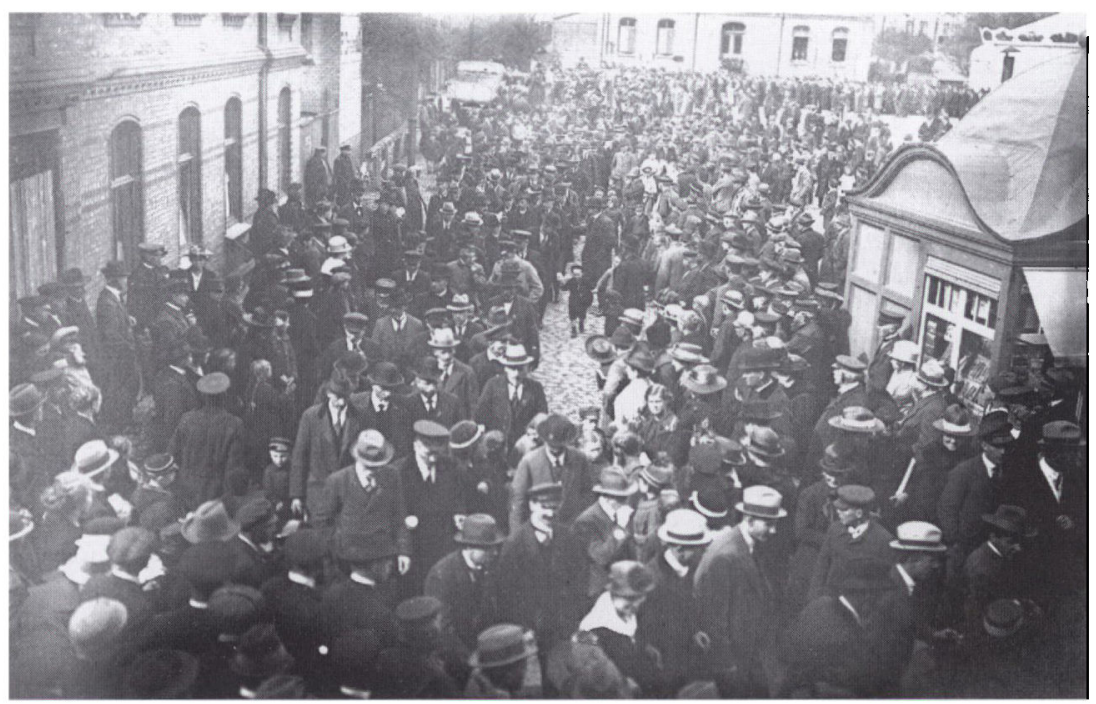

Generalstrejke i juni 1920 på Gravene $i$ Haderslev. Da kronemønten blev indført den 20. maj 1920 steg priserne efterfalgende eksplosivt. I de fire store nordslesvigske byer afholdt arbejderne generalstrejker i forste halvdel af juni måned, med krav om tilsvarende lønstigninger. På selve indlemmelsesdagen den 15. juni 1920 blev generalstrejkerne afblæst.

den 5. til den 15. juni. For at holde gas- og elektricitetsværkerne i gang måtte en nødtørftig "samfundshjælp « etableres, hvor en række håndværksmestre holdt gang $\mathrm{i}$ disse for samfundet mest nødvendige funktioner. Først den 12. juni lykkedes det at opnå et forlig med arbejderne. Med H.P. Hanssens medvirken blev der opnået enighed om en timeløn efter den i Danmark gældende for hvert fag, og samtidig skulle arbejdsgiverne sørge for, at priserne blev holdt på samme niveau som i Danmark. Til gengæld skulle arbejdet genoptages tirsdag den 15. juni om morgenen. ${ }^{62}$ Herefter tilpassede priserne sig langsomt det danske niveau, og roen blev genoprettet i Nordslesvig. Det hang også sammen med, at den nye grænse blev notificeret samme dag, tirsdag den 15. juni 1920. Dermed ophørte den tyske suverænitet over Nordslesvig, og toldgrænsen kunne endelig flyttes til 1. zones sydgrænse. Natten mellem den 16. og 17. juni forsvandt de tyske toldere ved Kongeågrænsen, og den 17. juni påbegyndte både det danske og det tyske toldvæsen deres opgaver ved den nye grænse. Endnu et stykke tid opretholdt den danske regering kontrollen ved Kongeåen for at forhindre storstilet toldfri vareindførsel fra Nordslesvig til Dan- 
mark. ${ }^{63}$ Mange nordslesvigske lagre var blevet fyldt med tyske varer før genforeningen i forsøget på at undgå toldmyndighederne.

\section{Lovene af 28. juni 1920 og implementeringen}

Den tyske regering havde godkendt, at suveræniteten over 1 . zone blev overdraget til Danmark fra den 15. juni, dog uden at skrive under på den tresidede traktat, som skulle være grundlaget for Nordslesvigs overgang til Danmark. ${ }^{64}$ I stedet måtte en kortfattet tosidet traktat underskrives af de allieredes hovedmagter og Danmark den 5. juli 1920, hvori den formelle overdragelse af Nordslesvig blev bekræftet. Med suverænitetsoverdragelsen den 15. juni kunne Folketinget endelig lovgive for Nordslesvig. Den 22. juni vedtog Landstinget de ændringer i grundloven, der var nødvendige for genforeningen, blandt andet en udvidelse af Folketinget og Landstinget. Den 25. juni blev der forelagt 76 lovforslag i Folketinget angående Nordslesvig. Dagen efter færdiggjorde Landstinget alle 76 love, der blev gjort gældende fra den 28. juni 1920. Fra og med den 28. juni var Nordslesvig endegyldigt en del af Danmark, da indlemmelsesloven trådte i kraft denne dag. Genforeningen kulminerede den 10. juli 1920, da kongen red over den gamle grænse ved Frederikshøj og ind i det danske Nordslesvig på sin hvide hest. ${ }^{65}$

Blandt de 76 love, der blev gældende fra den 28. juni, var også lovene om kronemøntens indførsel, udligningskassen og lånekassen. Med vedtagelsen den 28 . juni var valutaordningen langt om længe blevet kongelig dansk lov, efter at ordningen havde været gennem en mere end usædvanelig beslutningsprocedure. $\mathrm{Nu}$ var det op til de udnævnte bestyrelser, sønderjydsk valutaråd og kroneudvalget, at implementere henholdsvis udligningskassens og lånekassens bestemmelser og formål. Det skulle blive mere vanskeligt, end man havde forestillet sig. Et bevis for dette var, at Folketinget allerede den 22. december 1920 måtte vedtage en ændring i loven om udligningskassen. Endringen drejede sig om at udvide muligheden for renteregulering, således at personer der i 1914 havde haft formuer over 10.000 mark, kunne tilbydes renteregulering i stedet for en engangs kapitalregulering. Det vil sige, at personer med formuer over 10.000 mark $i$ 1914 i stedet for kapitalerstatning ad en gang, nu kunne opnå en livsvarig årlig renteudbetaling. Samtidig skulle renten ikke betales tilbage ved deres død, som bestemmelsen havde været i loven af 28 . juni. 
Lovændringen var særlig møntet på ældre uarbejdsdygtige personer og tidligere kreditorer. Herfra var der længe blevet protesteret over den først gældende ordning.

Med implementeringen af valutalovene kom der flere praktiske problemer. Først og fremmest lod hverken udligningskassens eller lånekassens virksomhed sig afslutte så hurtigt som først antaget. Udligningskassen havde per 1 . november 1922 haft en samlet udgift på 58.776.460 kroner, hvoraf 44.691 .655 kroner svarende til cirka 3/4, var udbetalt som almindelig kapitalerstatning. Kapitalværdien, det vil sige den fremtidige værdi af den samlede renteregulering, blev anslået til 14.084 .805 kroner. I alt 25.252 nordslesvigere havde søgt om erstatning ved udligningskassen. Dertil kom 1280 ansøgninger fra folk uden for det nordslesvigske område og et antal ansøgninger fra optanter, der endnu ikke var behandlet. I efteråret 1922 var 20.832 nordslesvigske ansøgninger blevet bevilget, og 4420 ansøgninger afvist. Det gav en afvisningsprocent på $17 \frac{1}{2}$. Den pligtmæssige kapitalerstatning for 1914-formuer under 10.000 mark udgjorde den største andel på 22,3 millioner kroner. De ikke-pligtmæssige erstatninger for 1914-formuer over 10.000 mark udgjorde dog næsten lige så stor en andel på 19,9 millioner kroner, hvortil også rentereguleringen skal lægges. Ifølge opgørelsen udgjorde det samlede tabte beløb under krigen og inflationen for erstatningsansøgerne omtrent 110 millioner kroner. Udligningskassens samlede udgift blev cirka 60 millioner, hvorved cirka $55 \%$ af det tabte beløb blev erstattet. Inflation og købekraft betyder, at tallene skal fortolkes varsomt. Opgørelsen viser dog, at der vitterligt gik store værdier tabt i Nordslesvig, som ikke blev erstattet umiddelbart. I 1923 indstillede udligningskassen sin virksomhed, hvorefter rentereguleringen blev ført videre af Finansministeriet. I den oprindelige lov var slutdatoen den 31. marts 1921.

Lånekassen havde brugt de til rådighed stående 10 millioner i foråret 1922, og for en tid blev arbejdet indstillet. I 1925 stillede staten yderligere 2 millioner til rådighed, og i 1927 yderligere 15 millioner kroner. Først da denne tredje bevilling var brugt, blev lånekassen nedlagt. ${ }^{66}$ I 1927 var der ydet over 21 millioner kroner i lån til Nordslesvig. Den danske stat måtte således involvere sig noget mere i den nordslesvigske økonomi, end det der blev lagt op til med valutaordningen i 1920. Valutaspørgsmålet havde vist, hvor vanskeligt det var at indlemme Nordslesvig smertefrit og blev på den måde en forsmag på den problemfyldte udvikling efter 1920. 


\section{KILDER}

\section{Rigsarkivet}

Det midlertidige ministerium for sønderjydske anliggender. (SM.) Journaler $\mathrm{m}$. registre 1919-20, Journal nr. 353/1919/ 1920.

Det sønderjydske udvalg af 1918 . Journal 1918-19, Journalsager 1919.

Det sønderjydske kroneudvalg 1919-22. Journalsager 1919-22, Formular I.

Udenrigsministeriets akter 1909-45. (UM.) Bekendtgorelser fra den internationale kommission for Slesvig. 7.B.34.b.

Danica-arkiv nr. 600. Public Record Office London. Foreign Office/852. 1919-21. International Plebicite Commission in Slesvig. Film 704-706.

Martin Hammerichs privatarkiv. 5531. Kammerherre Kriegers udvalg vedr. Slesvigs genforening med Danmark. pk.nr. 21.

Niels Neergaards privatarkiv. 6026. Korrespondancesager vedr. indlemmelsen af de sønderjyske landsdele. pk.nr. 101.

\section{Landsarkivet i Aabenraa}

Vælgerforeningen for Nordslesvig og dens forskellige underafdelinger. Betænkninger og sager vedr. Vælgerforeningens udvalg 1918-20, Fohandlingsprotokol for det $ø$. udvalgs underudvalg for landbrug. 1918-19. pk.nr. 35-36.

H.P. Hanssens privatarkiv. Korrespondancesager vedr. Nordslesvigs genforening med Danmark. 1919-22. pk.nr. 159.

\section{Kolding stadsarkiv}

Oluf Bechs personarkiv. Erindringer om tiden i Kolding. Hæefte 1-4.

\section{LITTERATUR OG TRYKTE KILDER}

Adriansen, Inge (1996): "Nødpenge « i Sdj. månedsskrift nr.1/2 1996. s. 32. Historisk Samfund for Sønderjyland. Aabenraa.

Becker-Christensen, Henrik (1995): „Den nye grænse. i i Henrik Becker-Christensen (red.) Grænsen $i 75$ år 1920-1995. s. 24-43. Institut for grænseregionsforskning. Aabenraa.

Beretning fra Udvalget for Afhjolpning af de med Kronemontens Indforelse $i$ Sønderjylland forbundne Vanskeligheder. Kobenhavn 1921. (Det kgl. bibliotek).

Beretning om Virksomheden $i$ Udligningskassen for de sonderjydske Landsdele. J.H. Schultz. København 1922. (Det kgl. bibliotek).

Callø, P.A. (1922): "De økonomiske forhold i Sønderjylland i overgangstiden «. I National-økonomisk Tidskrift for Samfundsspørgsmaal, Økonomi og Handel. 1922. s. 188-229. Nordisk forlag. København.

Fangel, Henrik (1996): Haderslev bys historie 1864-1920. Historisk Samfund for Sonderjylland nr. 74. Haderslev og Aabenraa.

Feldman, Gerald D. (1997): The Great Disorder. Politics, Economics and Society in the German Inflation, 1914-1924. Oxford University Press.

Fink, Troels (1953): "De økonomiske problemer ved Nordslesvigs genforening med Danmark « i Danmarks erhveroshistoriske årbog. 1953. s. 100-106.

Fink, Troels (1979): Da Sønderiylland blev delt $B d$. I-III. Institut for grænseregionsforskning. Aabenraa.

Forhandlinger $i$ Rigsdagspartiernes sønderjydske Udvalg 1919-20.

Furdal, Kim (1999): Fra preussiske landkommuner til danske sognekommuner. Kommunestyret $i$ Sonderjylland fra 1867 til 1920 'erne. Historisk Samfund for Sønderjylland nr. 79. Aabenraa.

Hübbe, Christian (1931): "De sønderjydske Pengeinstitutter i Overgangstiden og efter Genforeningen samt Oplysninger om Kredit- og Pengeforholdene i Sønderjylland." i Sonderjydske Aarbøger 2. rakke 1931. s. 1-87. Historisk Samfund for Sønderiylland. Aabenraa.

Lovtidende for Kongeriget Danmark for Aaret 1920. (og 1915) Afdeling A1. J. H. Schultz A/S. Kobenhavn 1916 og 1921.

Poulsen, Marten Refslund (1957): Erindringer. 2. del. Genforeningen i Nordslesvig. Det danske forlag. Kobenhavn.

Rasmussen, Troels (1996): Den dansk-tyske traktat 1922. Den praktiske ordning af den nye grænse mellem Danmark og Tyskland. Institut for Grænseregionsforskning. Aabenraa. 
Rigsdagstidende. Forhandlinger paa Folketinget. 71de ordentlige samling 1918-19. III. J.H. Schultz. A/S. København 1919.

Schultz Hansen, Hans (1994): Det sonderjyske landbrugs historie 1830-1993. Historisk Samfund for Sønderjylland nr. 72. Aabenraa.

Thomsen, Kresten Refslund (1926): "Den finansielle Udvikling i de sønderjydske Landsdele før, under og efter Krigen.« $i$ Senderjydske Aarbøger 1926. s. 78-115. Historisk Samfund for Sønderjylland. Aabenraa.

\section{NOTER}

1. UM. 7.B.34. Anordninger fra den internationale kommission i Slesvig.

2. Lov nr. 292 af 28 . juni 1920 om Indforelse af dansk Mønt. Lovtidende 1920. s. 1124.

3. Lov Nr. 297 af 28 . juni 1920 om en Udligningskasse for de sønderjydske Landsdele. Lovtidende 1920 . s. 1125.

4. Lov Nr. 298 af 28 . juni 1920 om en Laanekasse i Sonderjylland. Lovtidende 1920. s. 1123.

5. Rigsdagspartiernes sønderjydske Udvalg. Forhandlingsprotokol. s. 977982.

6. Callø (1922) s. 189.

7. Schultz Hansen (1994) s. 213.

8. Callø (1922) s. 191.

9. Schultz Hansen (1994) s. 214.

10. Callø (1922) s. 194-195.

11. Fangel s. 386-88 og Schultz Hansen (1994) s. 216-17.

12. Fangel. s. 405.

13. Fangel s. 399 og Furdal s. 59-60.

14. Fangel s. 405 .

15. UM. 7.B 34.

16. Beretning 1921. s. 3.

17. Feldman s. 134-135. Kapitalflugten til Nordslesvig var grundet $\mathrm{i}$ områdets sandsynelige adskillelse fra Tyskland og tyske skattemyndigheder.

18. Refslund Thomsen s. 88-90.

19. Handelsudvalget: Holger Fink og Sophus Thomsen. Landbrugsudvalget: $H$. Andresen, J. Høyer, Konsulent Hansen og Konsulent Johs. Jensen. Industriudvalget: Direktør Christensen og Direktør Aage Gram.
Håndværkerudvalget: J. Christensen og væver Th. Kaufmann.

20. Betænkning 1919. s. 3.

21. Martin Hammerichs privatarkiv pk.nr. 21. Betænkning.

22. Martin Hammerichs privatarkiv. Kriegerudvalgets Forhandlingsprotokol.

23. Betænkningen findes blandt andet i Nordslesvigsk Vælgerforenings arkiv. Pk.nr. 35-36.

24. Refslund Poulsen s. 55.

25. Callø (1922) s. 196.

26. Hübbe (1925) s. 100-101.

27. Martin Hammerich's privatarkiv. Kriegerudvalgets forhandlingspotokol.

28. Hejmdal 30. april 1919.

29. Bl.a. Thomas Ries i Hejmdal den 8. maj 1919, handelsforeningerne i Hejmdal den 2. maj og Jens Hoyer, Billeslund, i Modersmaalet den 8 . maj.

30. Hejmdal 19. maj 1919.

31. Martin Hammerich's privatarkiv. Kriegerudvalgets forhandlingsprotokol.

32. Rigsdagstidende. 71de ordentlige samling 1918-19 III. sp. 5802-5803.

33. Ibid. sp. 5887-5890.

34. Rigsdagspartiernes sønderjydske Udvalg. Forhandlingsprotokol s. 1.

35. Ibid. s. 48.

36. Nationalbanken, Landmandsbanken, Handelsbanken, Privatbanken og Laane- og Diskontobanken.

37. Rigsdagspartiernes sønderjydske Udvalg. Forhandlingsprotokol. s. 89.

38. Gruppen bestod af Chr. Hübbe, Holger Fink, J. Hoyer, I.H. Koch, J. Møller, J. Thomsen, Sophus Thomsen, A. Sabroe, L. Christensen og F. Christensen.

39. SM. Journal nr. 353/1919.

40. Rigsdagspartiernes sonderjydske Udvalg. Forhandlingsprotokol. s. 94.

41. Gruppen bestod af P.A. Callø, Marten Refslund Poulsen, $\mathrm{H}$. Andresen, H.D. Kloppenborg-Skrumsager, J.H. Schmidt, Johannes Jensen, Hans Hansen, Th. Kaufmann og F. Christensen.

42. Callø (1922) s. 203.

43. Neergaard (formand) og Dalsgaard fra Venstre, Harboe og Schovelin fra de konservative, Sigvald Olsen (erstattedes senere af Borgbjerg) og Bramsnæs fra socialdemokratiet, Gunnar Fog-Petersen og Jens Ander- 
sen fra de radikale (erstattedes senere af P. Munch og Ove Rode). Rigsdagspartiernes sønderjydske Udvalg. Forhandlingsprotokol s. XV.

44. Resolution fra sønderjyske handelsforeninger 27/8 1919, H.P. Hanssens privatarkiv. pk. nr. 159 og Betænkning fra sønderjyske handelsforeninger 4/9 1919, i SM. Journalnr. 353/ 1919.

45. Rigsdagspartiernes sønderjydske Udvalg. Forhandlingsprotokol s. 368.

46. Beretning 1921. s. 3 .

47. SM. Journalnr. 353/1920.

48. Fink (1979) II s. 200-205.

49. Rigsdagspartiernes sønderjydske Udvalg. Forhandlingsprotokol s. 530.

50. Ibid s. 525.

51. Rigsdagstidende 71de ordentlige samling 1918-19 III sp. 7519. Genforeningslånet var et statsligt lån $\mathrm{i}$ form af salg af $5 \%$ statsobligationer.

52. I december 1920 opgjorde Emil Glückstadt erstatningssummen til Tyskland til 77. millioner kroner. Beretning fra Glückstadt til statsmin. Neergaard 17. december 1920. Neergaards privatarkiv. pk.nr. 101.

53. Becker-Christensen s. 41.

54. Flensborg Avis den 24. februar 1920. "Senderjysk Næringsliv og kongerigsk Konkurrence«.

55. Rigsdagspartiernes sønderjydske Udvalg. Forhandlingsprotokol s. 723724.

56. Becker-Christensen s. 42.

57. Danmarks Riges Grundlov. Lovtidende 1915, s. 11-624.

58. Rigsdagspartiernes sønderjydske Udvalg. Forhandlingsprotokol s. 977991.
59. UM. 7.B.34.

60. Niels Neergaards privatarkiv pk.nr. 101 og Flensborg Avis 12. maj 1920.

61. Bech's erindringer. Kolding Stadsarkiv.

62. Flensborg Avis 4. og. 5. juni 1920 og Fangel s. 437-439.

63. Fink (1979) III. s. 196.

64. Den tresidede traktat skulle underskrives af Danmark, Tyskland og ambassadørrådet $i$ Paris og indeholdt paragraffer om selve overdragelsen af suveræniteten, optionsbestemmelser for personer i 2 . zone der onskede at flytte til Danmark, Danmarks overtagelse af statsejendomme og nedsættelsen af en dansk-tysk kommission, som skulle ordne alle problemer der måtte opstå i forbindelse med overgangen. Tyskland modsatte sig traktaten grundet utilfredshed med optionsbestemmelserne, og på grund af tidspresset underskrev kun Danmark og ambassadørrådet. Danmark og Tyskland pabegyndte forst forhandlinger igen i maj 1921, efter at en grænseafstikningskommission havde fastsæt den endelige og helt konkrete grænselinie. En række administrative og økonomiske problemer var stadig uløst, og den danske og tyske regering måtte sammen løse disse. Det drejede sig om grænsens vedligeholdelse, finansielle spørgsmål, optionsbestemmelserne og arkivoverdragelser. Traktaten blev undertegnet den 22. april 1922. Se Troels Rasmussen "Den dansk-tyske traktat 1922 "(1996).

65. Fink (1979) III s. 213-217.

66. Hübbe (1931) s. 37-40. 